The following is a non-peer reviewed EarthArXiv preprint. This manuscript has been submitted for peer review to the journal Earth and Planetary Science Letters.

\title{
A proxy-model comparison for mid-Pliocene warm period hydroclimate in the Southwestern US
}

\author{
Sofia Menemenlis ${ }^{\mathrm{a}, *}$, Sarah M. White ${ }^{\mathrm{b}}$, Daniel E. Ibarra ${ }^{\mathrm{c}, \mathrm{d}}$, Juan M. Lora ${ }^{\mathrm{a}}$ \\ ${ }^{a}$ Dept. of Earth and Planetary Sciences, Yale University, New Haven, CT \\ ${ }^{b}$ Dept. of Geography, UC Berkeley, Berkeley, CA \\ ${ }^{c}$ Dept. of Earth and Planetary Science, UC Berkeley, Berkeley, CA \\ ${ }^{d}$ Dept. of Earth, Environmental and Planetary Sciences and the Institute at Brown for Environment \\ and Society, Brown University, Providence, $R I$
}

Keywords: Pliocene, Proxy-model comparison, Lakes, Paleoclimate

${ }^{*}$ Corresponding author; current institution: Program in Atmospheric and Oceanic Sciences, Princeton University, Princeton, NJ

Email address: smenemenlis@princeton.edu (Sofia Menemenlis) 


\begin{abstract}
Hydroclimate proxy reconstructions and paleoclimate models of the midPliocene warm period provide insight into how, under a moderate greenhouse warming scenario, Earth-system feedbacks may impact regional hydroclimate. However, in the Southwestern United States there is discord between these two types of information: proxy data have been interpreted to indicate much wetter conditions, while the most recent generation of mid-Pliocene warm period climate models simulates drying. We use a water and energy balance framework to directly compare paleoclimate model output to a refined compilation of proxy records of the presence and areal extent of mid-Pliocene lakes. Within this framework, we quantify uncertainties in the proxy system model parameters and in the interpretation of available proxy records. We find that despite these significant uncertainties, most paleoclimate models simulate a regional balance between precipitation and evaporative demand that could not have sustained the extent of recorded lakes from this time. Moreover, the extensive lakes included as boundary conditions in mid-Pliocene warm period climate models are inconsistent with the regional climate simulated by those same models. This study identifies and quantifies the remaining unknowns in our picture of regional mid-Pliocene warm period hydroclimate, with implications for analyses of climate dynamics during this time.
\end{abstract}

\title{
1. Introduction
}

Climate models project that global warming and regional drying in the American Southwest will exacerbate ongoing problems of water scarcity, drought, and wildfire in coming decades (e.g., Seager and Vecchi, 2010; Williams et al., 2020), but natural variability on decadal timescales muddles our predictions of the timing and magnitude of anthropogenic changes. Past climate states, as understood through proxy reconstructions and paleoclimate models, provide additional insight into how regional hydroclimatic conditions change over long timescales, and into the forcings and mechanisms responsible for these changes. The mid-Pliocene warm period 3.3-2.9 Ma is the most recent example of the long-term Earth-system response to elevated warmth and near-modern $\mathrm{CO}_{2}$ concentrations (Tierney et al., 2020); consequently, research efforts in proxy reconstruction and paleoclimate modeling have focused on this time period and region.

In contrast to climate model projections of future drying, published reconstructions of the mid and late Pliocene (3.6-2.6 Ma) hydroclimate indicate that the Western US was generally wetter than present by multiple measures. Compilations of Pliocene flora and faunal records, as well as stable isotope data, have been interpreted as evidence for higher-than-present mean annual precipitation (Molnar and Cane, 2007; Salzmann et al., 2008; Winnick et al., 2013). The presence and size of pluvial lakes record climate-driven changes in water availability over time, so records from outcrops, shorelines, and cores of these 
lakes provide another archive of past climate conditions. Today, the internallydraining Great Basin region in the Western United States includes a few modestly sized lakes, but published records indicate more extensive lakes during the Pliocene between 3.6-2.6 Ma (Pound et al., 2014). Under conditions of increased warmth and higher evaporative demand, these lakes could have only been sustained by higher-than-modern precipitation (Ibarra et al., 2018).

The Mediterranean-type climate of the western US is shaped by dynamical processes associated with the subtropics and midlatitudes: subtropical highs bring hot, dry summers, while extratropical storm tracks bring most of the region's precipitation during the winter (Seager et al., 2019). The climate modeling studies invoked to explain wetter Pliocene conditions in the region have predominantly focused on changes in the meridional Hadley circulation and feedbacks from the tropical Pacific: Burls and Fedorov (2017), using a model tuned to reproduce the reduced meridional and zonal temperature gradients indicated by proxy reconstructions of the early Pliocene, demonstrate that a weakened zonal-mean Hadley circulation would have increased precipitation minus evaporation in subtropical regions between 10-30 degrees latitude, including in parts of southwestern North America. And, following studies linking reduced temperature gradients to a permanent El Niño-like state during the Pliocene (e.g., Wara et al., 2005; Fedorov et al., 2006), others attribute wetterthan-modern conditions in western North America to extratropical teleconnection patterns similar to those associated with modern El Niño events (Molnar and Cane, 2007; Goldner et al., 2011; Winnick et al., 2013). Although this work has been cited to explain mid-Pliocene warm period conditions and analogize to future warming (Ibarra et al., 2018; Tierney et al., 2020), the magnitude of tropical Pacific sea surface temperature (SST) gradients in the Pliocene is still disputed: some analyses of proxy data argue for only modest reductions in the zonal gradient (Zhang et al., 2014; O'Brien et al., 2014; Tierney et al., 2019), while others argue for considerable reductions (Ravelo et al., 2014; Wycech et al., 2020; White and Ravelo, 2020). Meanwhile, Pliocene climate models are similarly equivocal: both older (Brierley et al., 2015) and more recent generations of models show a general decrease in El Niño-Southern Oscillation amplitude and a slight reduction in the zonal SST gradient, but do not agree on whether there was a shift to an El Niño-like mean state (Brierley et al., 2015; Oldeman et al., 2021).

Moreover, recent modeling studies highlight the influence of mid-Pliocene ice, vegetation, and orography reconstructions, used as boundary conditions in climate models (PRISM4; Dowsett et al., 2016), on terrestrial hydroclimate. Feng et al. (2021) present sensitivity simulations demonstrating that Pliocene ice sheets and vegetation cause wetter conditions in the Sahel and subtropical east Asia, particularly in Boreal Summer (June-September). This influence does not extend to moister conditions in the US southwest. Pliocene boundary conditions instead have a drying effect there: sensitivity simulations using the UofT-CCSM4 Pliocene model demonstrate that Pliocene ice sheets and orography, applied separately or in combination, alter Northern Hemisphere wintertime stationary waves and divert North Pacific atmospheric rivers away from 
western North America, leading to a regional decrease in extreme precipitation and drier conditions in the annual mean (Menemenlis et al., 2021). Taken together, modeling studies of the mid-Pliocene hydrologic cycle indicate that the hydroclimate of the Western United States is sensitive to dynamical changes in tropical and extratropical circulation patterns, but that the interplay between these processes during the mid-Pliocene warm period is still ambiguous.

The Pliocene climate was more stable than the Pleistocene, but the midPliocene nonetheless experienced variability due to changes in Earth's obliquity and precessional cycle (Haywood et al., 2002). Orbital changes would have influenced temperatures, precipitation patterns, and seasonality through feedbacks from ice sheets and vegetation (Willeit et al., 2013; Haywood et al., 2013a; Prescott et al., 2014). Given the sensitivity of major spatial features of modeled midlatitude terrestrial hydroclimate to such processes (e.g., Feng et al., 2021; Chan and Abe-Ouchi, 2020; Menemenlis et al., 2021), it is important to consider how regional hydroclimate might have changed over orbital timescales during the mid-Pliocene warm period. While the lack of precise temporal constraints on terrestrial proxies poses a challenge for model-data comparison (Haywood et al., 2013a; Salzmann et al., 2013), the timing of pluvial lakes can be assessed with relative accuracy using a combination of paleomagnetic and stratigraphic methods. In cases where proxy records are dated with $<10 \mathrm{kyr}$ accuracy, new climatic interpretations are made possible. For example, Knott et al. $(2018,2019)$ use updated tephrochronology and ${ }^{40} \mathrm{Ar} /{ }^{39} \mathrm{Ar}$ dating to constrain the ages of South Great Basin lake deposits; they argue that the presence of lakes in Eureka Valley and Death Valley before $~ 3.3$ Ma was a result of glacial conditions, and their subsequent absence was caused by warmer and regionally drier interglacial conditions. Such analyses suggest that temporal constraints on proxy records could significantly affect our view of regional hydroclimate conditions and model-data fit.

A key aim of the most recent set of coordinated mid-Pliocene warm period modeling experiments (from the Pliocene Model Intercomparison Project version 2, PlioMIP2) is to reduce uncertainty associated with the "time-slab" approach of PlioMIP1, which aimed to simulate the average of warm interglacial periods from 3.264 - 3.025 Ma. PlioMIP2 targets a "time-slice" of 3.207-3.204 Ma during the KM5c interglacial at 3.205 Ma. Using an updated set of boundary conditions, notably including closed Arctic Gateways, these simulations achieve a closer match between the multi-model mean and reconstructed SSTs (Haywood et al., 2020). However, while PlioMIP1 simulated wetter conditions in the Western US, PlioMIP2 simulates drying across much of the US Southwest (Haywood et al., 2020), largely driven by a decrease in cool-season precipitation (November-April, see Figure S1). This leaves a discrepancy between the general evidence for wetting in the Pliocene western US, with widespread lakes in the region included as boundary conditions in PlioMIP2 models (Pound et al., 2014; Dowsett et al., 2016), and the drying simulated by the PlioMIP2 multimodel ensemble.

To understand the nature of and influences on Pliocene hydroclimate in the US Southwest, we first must understand the (dis)agreement between existing 
proxy reconstructions and paleoclimate model output. The "PMIP triangle" describes three broad causes of model-data discrepancies: uncertainties in proxy data, climate model boundary conditions, and climate model physics (Haywood et al., 2013b, 2016). We ask the following questions. Given unresolved orbital variability in proxy data, does the mismatch between proxies and models stem from differences in the time periods captured by each? Or do PlioMIP2 models, in their reliance on imperfect model boundary conditions and incomplete model physics, underestimate precipitation in the region? Or, is there too much uncertainty in the available evidence to discern either way? Building on Ibarra et al. (2018), we use a proxy-system model approach to compare an updated compilation of proxy evidence for mid-Pliocene lakes to climate model output from PlioMIP2.

\section{Methods}

\subsection{Regional setting}

We focus on a 93,000 $\mathrm{km}^{2}$ area of the Great Basin covering much of Eastern California and some parts of Western Nevada (see Supplement Section 1.1). This "South Great Basin" area, shown in Figure 1, encloses a group of contiguous watersheds including Owens, China, Searles, Panamint, and Death Valleys, which, under wetter (i.e., Last Glacial Maximum) conditions, formed an interconnected system of lakes and rivers (Reheis et al., 2014; Knott et al., 2019). At present, the South Great Basin experiences an arid desert and steppe climate, bordered to the northwest by the warm temperate climate of the Sierra Nevada. Most precipitation arrives in the wintertime (Figure S1). The ensemble of ten PlioMIP2 climate models used in this study predicts a $3.4^{\circ}$ increase in temperature and a (mostly cool-season-driven) $0.13 \mathrm{~mm} \mathrm{~d}^{-1}$ decrease in annual-mean precipitation across this region (Figures S1 and S2). Since the mid-Pliocene warm period, tectonic factors have evidently had a secondary influence to climatic ones on the overall presence and size of lakes: Since $3 \mathrm{Ma}$, the Sierra Nevada has risen and tilted toward the Pacific (Mix et al., 2019), deepening the valleys of the South Great Basin to the east (note that this change is not captured by the paleogeographic reconstruction used in PlioMIP2 boundary conditions). Higher Pliocene elevations in the South Great Basin would have slightly affected lake surface evaporation rates (Equation 5); our results are insensitive to these elevation-driven changes in evaporation (Figure S3). And despite uplift of the Sierra Nevada, precipitation isotope data indicate that deflection and blocking leading to the Sierra Nevada rain shadow have remained fairly constant since the Pliocene (Mix et al., 2019).

\subsection{Proxy compilation}

We assemble a compilation of South Great Basin lakes that existed between 3.21-3.20 Ma, drawing on previous compilations of Pliocene hydroclimate proxy data, as well as recently published studies (Table S1). For each lake, we gather 
paleoenvironmental and stratigraphic information from sediment cores, outcrops, and geophysical data, with particular attention to dating methods, from the original literature. To estimate lake areas, we use estimates from the original literature or from Pound et al. (2014), where possible. In some cases, we estimate lake area based on areal extent of the outcropping sediments. Lake areas in the original literature and from Pound et al. (2014) are based on outcrops recording lake level highstands; to estimate lowstands for perennial lakes, we use the area of the modern playa, on the basis that continuous sedimentation around 3.2 Ma implies that a perennial lake present in the Pliocene (but not today) occupied the area of its modern playa, at a minimum. In the case of Amargosa Marsh, we take one half the highstand value as a conservative estimate of lowstand, since widespread outcrops in the region show no evidence of desiccation.

We present three scenarios_-"wet," "intermediate," and "dry"- to represent a range of interpretations of lake areas during the 3.21-3.20 Ma period. The dry scenario is composed only of the lowstands of perennial lakes, defined as lakes with 1) a continuous stratigraphic record through the 3.21-3.20 Ma interval supported by unambiguous dating, and 2) no evidence of desiccation. The intermediate scenario includes perennial lakes at their highstands. The wet scenario includes perennial lakes at their highstand as well as "ephemeral" lakes, which meet condition 1 but not condition 2, and "potential" lakes. Potential lakes include those for which there are no Pliocene outcrops or drill cores, but geophysical data indicate a deep basin fill of probable Pliocene age (e.g., Owens Lake). Potential lakes also include those with outcrop evidence of lacustrine conditions, but poor dating (e.g., Mono Lake). The difference between the wet and dry scenarios is thus a measure of uncertainty, reflecting uncertainty in dating and lake extent, as well as limitations of interpretation and extrapolation based on available data. Further details of dating and lake area estimation for each lake are given in Table S1.

\subsection{Modeling framework}

To directly compare between the proxy compilation and climate model data, we update the proxy-system model described in Ibarra et al. (2018). This model assumes a simplified steady-state balance between volumetric fluxes of water into and out of a system of pluvial lakes:

$$
\frac{d V}{d t}=\text { Runoff }+ \text { Precipitation }- \text { Evaporation }=0
$$

This water balance can be expressed in terms of basin area and lake area, as follows:

$$
P k_{\text {run }}\left(A_{B}-A_{L}\right)+P A_{L}=E_{L} A_{L}
$$

where $P$ is precipitation, $k_{\text {run }}$ is the fraction of $P$ converted to runoff, $A_{B}$ is the area of a terminal basin, $A_{L}$ is lake area, and $E_{L}$ is lake evaporation. Rearranging equation 1 ,

$$
\frac{A_{L}}{A_{B}}(\%)=\frac{P k_{\text {run }}}{E_{L}-P+P k_{\text {run }}} \times 100 .
$$


We use the Priestley-Taylor equation (Priestley and Taylor, 1972) to determine $E_{L}$. The latent heat flux over the surface of a lake, expressed as $L E_{L}$, where $L$ is the latent heat of evaporation and $E_{L}$ is the rate of evaporation, is determined as follows:

$$
L E_{L}=\alpha\left(\frac{\Delta}{\Delta+\gamma}\right) R_{N} .
$$

The constant $\alpha$ is empirically determined. $R_{N}$ is the net downward radiation flux at the surface, which can be expressed as the sum of the surface radiation fluxes $R_{s, i}-R_{s, o}+R_{l, i}-R_{l, o}$, where the subscripts $s, l, i$, and $o$ denote shortwave, longwave, incoming, and outgoing radiation, respectively. $\Delta$ is the temperature-dependent slope of the saturation vapor pressure curve in $\mathrm{kPa} \mathrm{K}^{-1}$ :

$$
\Delta=\frac{4098\left(0.6108 \times \exp \left(\frac{17.27 T}{T+237.3}\right)\right)}{(237.3+T)^{2}},
$$

where $T$ is temperature. $\gamma$ is the psychrometric constant, which is elevationdependent and which we calculate following Allen et al. (1998):

$$
\gamma=\frac{c_{p} p}{\epsilon \lambda}=0.665 \times 10^{-3} p,
$$

where $c_{p}$ is the specific heat of water at constant pressure, $\epsilon$ is the ratio of the molecular weights of water vapor and dry air, $\lambda$ is the latent heat of vaporization of water, and atmospheric pressure $p$ depends on elevation $z$. Pressure $p$ is approximated by:

$$
p=p_{0}\left(\frac{T_{0}-\Gamma z}{T_{0}}\right)^{\frac{-g M}{R \Gamma}},
$$

where $p_{0}$ and $T_{0}$ are reference pressure and temperature, $R$ is the ideal gas constant, $g$ is gravitational acceleration, $M$ is the molar mass of air, and $\Gamma$ is the environmental lapse rate $0.0065 \mathrm{~K} \mathrm{~m}^{-1}$.

The Budyko relationship relates $k_{\text {run }}$ to the prevailing long-term climatic conditions of a catchment. We use the following analytical formulation from $\mathrm{Fu}$ (1981); Zhang et al. (2004):

$$
1-k_{\text {run }}=\frac{E T}{P}=1+\frac{E_{p}}{P}-\left[1+\left(\frac{E_{p}}{P}\right)^{\omega}\right]^{1 / \omega} .
$$

$E_{P}$ is the potential evapotranspiration, which we initially calculate using the "energy-only" method in which $E_{P}=R_{N} / L_{V}$, where $L_{V}$ is the latent heat of vaporization $2264.76 \mathrm{~kJ} \mathrm{~kg}^{-1}$. This method has been shown to capture $E_{P}$ reasonably well in modern climates (Roderick et al., 2014; Scheff and Frierson, 2014), even as compared to more data-intensive methods for estimating $E_{P}$ (e.g., Milly and Dunne, 2016). The amount of precipitation converted to runoff is a monotonic function of the aridity index $E_{P} / P$, with variations across space and time captured by the parameter $\omega$. The Budyko relationship is most reliable when considering large areas $\left(10,000 \mathrm{~km}^{2}\right.$ or larger) and using long-term climatological data (Donohue et al., 2007). 
After finding modern values of $A_{L} / A_{B}$ (see next section), we vary annual mean surface temperature and precipitation over reasonable ranges, and calculate how this impacts $A_{L} / A_{B}$. Precipitation appears directly in the right-hand side of equation 2 and impacts $k_{\text {run }}$ via equation 7. $R_{N}$ and $E_{P}$ both increase with temperature, so changes in temperature affect $E_{L}$ via equation 3 , and $k_{\text {run }}$ via equation 7. Our approach using absolute changes in precipitation contrasts with Ibarra et al. (2018), who use proportional changes in precipitation. This modification does not affect our conclusions (Figure S4), but using absolute precipitation changes more clearly conveys the magnitude of precipitation increases that would be necessary to produce the $A_{L} / A_{B}$ values inferred from proxy reconstructions.

\subsection{Modern lake areas from reanalysis}

Modern lake areas are the baseline for our forward modeling. We use 41 years $(1980-2020)$ of $0.5^{\circ}$ latitude $\times 0.625^{\circ}$ longitude fields of observationallycorrected precipitation, skin temperature, surface radiation, and topography from the Modern-Era Retrospective Reanalysis for Research and Applications, Version 2 (MERRA2; see Supplement Section 1.3). To verify that this product captures the spatial heterogeneity within and around the South Great Basin, we apply the proxy-system model described in the previous section to each grid cell, using representative values of $\omega=2.6$ and $\alpha=1.6$. Although these calculations do not account for uncertainties or spatial differences in model parameters, the model reasonably predicts the presence and extent of lakes across the broader Great Basin region (Figure 1).

We use a single $A_{L} / A_{B}$ to represent the entire South Great Basin region. We find $P, k_{r u n}$, and $E_{L}$ for each reanalysis grid cell within the South Great Basin region, then take their sum to find an overall basin-normalized lake area for the entire region. This approach is a compromise between the small spatial scales of lake basins and the coarse spatial scales of reanalysis and climate model data (cf. Ibarra et al. (2018)). It implicitly accounts for overflow between grid cells, and allows calculated lake areas to remain accurate even if individual drainage regions within the South Great Basin were reconfigured over time, for example by tectonic changes. However, the model does not see spatial differences in $\omega$ or other parameters.

When applied to MERRA2 data, the model reproduces the combined area of observed modern lakes in the South Great Basin. The modern $A_{L} / A_{B}$ of perennial lakes (including Owens Lake, which in the 1920s was desiccated by human activity) is $0.5 \%$, and the combined area of perennial and seasonal/ephemeral lakes is $1.5 \%$ (see Supplement Section 1.2). The model parameters needed to reproduce areas in this range are reasonable: the $\omega$ range of 2.4-3.1, with a mean of 2.7, compares favorably to the US average of 2.6. And although direct measurements of $\omega$ are sparse, this range encompasses empirically determined $\omega$ values of 2.4 and 2.6 for two small watersheds on the eastern side of the Sierra adjacent to the South Great Basin region (Greve et al., 2015, see Figure 3a). 
a.

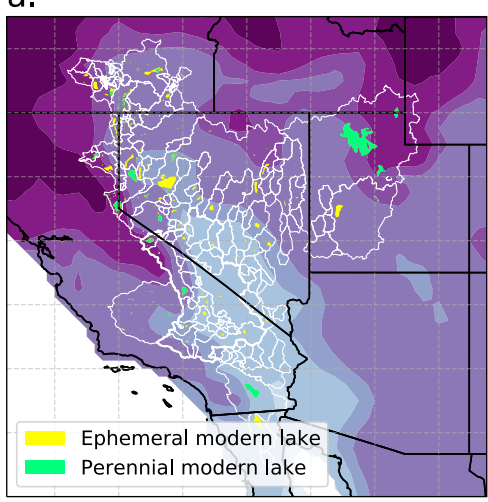

b.

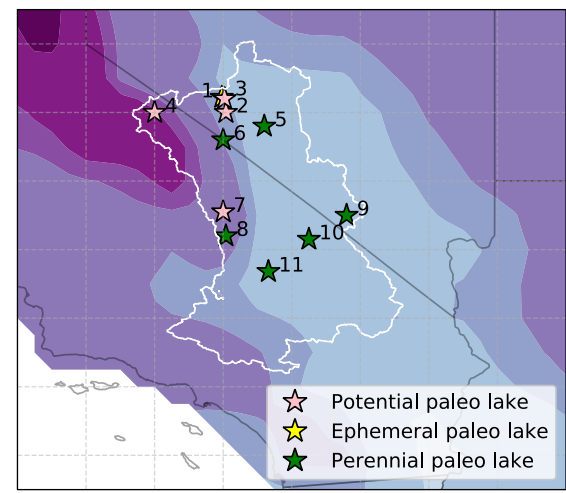

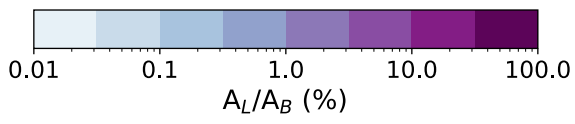

Figure 1: Modern $A_{L} / A_{B}$ calculated for each grid cell using MERRA2 reanalysis data, with $\omega=2.6$ and $\alpha=1.26$. (a) Modern drainage areas indicated by thin white lines, and South Great Basin region indicated by thick white lines. Modern perennial lakes, including Owens lake, shown in green; modern ephemeral lakes shown in yellow. (b) Close-up of South Great Basin region, with Pliocene proxy sites marked by pink, yellow, and green stars respectively indicating potential, ephemeral, and perennial lakes. (1) Redlich Summit, (2) Columbus Salt Marsh (3) Rhodes Salt Marsh (4) Mono Lake, (5) Clayton Valley, (6) Fish Lake Valley, (7) Coso Basin, (8) Owens Lake, (9) Amargosa Marsh, (10) Copper Canyon Formation, (11) Searles Lake.

\subsection{Parameter uncertainty}

Each model parameter introduces some uncertainty to our estimate of $A_{L} / A_{B}$. To quantify the combined uncertainty due to these parameters, we estimate the uncertainty in each parameter, then propagate these uncertainties using a Monte-Carlo framework.

Lake areas are sensitive to the parameter $\omega$. The Fu (1981) analytical formulation of the Budyko relationship (Equation 7) incorporates $\omega$ to account for the observation that runoff amounts are affected not only by $P$ and $E_{p}$, but also by changes in vegetation, soil properties (i.e., soil type and depth), topographic characteristics, fire, and the seasonality of $P$ and $E$ (Roderick and Farquhar, 2011, others). As $\omega$ increases (decreases), the amount of precipitation converted to runoff decreases (increases), and lake areas decrease (increase). Figure 2a shows how changing $\omega$ affects modern South Great Basin $A_{L} / A_{B}$ as determined using MERRA2 reanalysis.

Because $\omega$ has no definitive physical meaning and is impacted by a suite of catchment hydrology and vegetation characteristics, Greve et al. (2015) treated the combined impact of all catchment characteristics bearing on $\omega$ as a stochastic process, and identified a right-skewed gamma distribution as representative of the range of empirical measurements of $\omega$ for catchments in the United States. We use the range of $\omega$ values within this distribution that produce reasonable 
areas for the present-day South Great Basin (blue points in Figure $2 \mathrm{~b}$ ). Changes in $\omega$ between the Pliocene and present-day might have had an effect on the fraction of precipitation converted to runoff; we discuss this caveat in section 4 .

The Priestley-Taylor equation includes an empirically determined parameter $\alpha$. This constant encodes the extent to which characteristics of the atmospheric boundary layer and overlying atmosphere cause actual evapotranspiration to diverge from potential evapotranspiration (Priestley and Taylor, 1972), and over water surfaces is determined by the relative transport efficiency of turbulent heat and water vapor (Assouline et al., 2016). Priestley and Taylor (1972) estimated $\alpha=1.26$ for saturated surfaces; subsequent observational and theoretical studies confirmed that, for advection-free situations over water, $1.20<\alpha<1.30$ (Brutsaert, 2005; Assouline et al., 2016). Figure 2a demonstrates that the impact of variations in $\alpha$ between 1.2-1.3 is small compared to $\omega$.

We parameterize how $R_{N}$ and $E_{P}$ scale with temperature. $R_{N}$ increases with greenhouse warming as surface long-wave radiation increases. Previous studies analyzing climate model output from Coupled Model Intercomparison Project (CMIP) Phase 3 and 5, and from paleoclimate models, find that $R_{N}$ increases by approximately 0.9-1.6\% per K warming (Fu and Feng, 2014; Roderick et al., 2014; Ibarra et al., 2018). $E_{P}$ increases with temperature at a higher rate than $R_{N}$. Although $R_{N}$ contributes to the increase in $E_{P}$, the direct physical effects of warming are more consequential: warmer near-surface air temperatures increase both saturation vapor pressure and the slope of the saturation vapor pressure curve $\Delta$, resulting in higher rates of evaporation off of a wellwatered surface (Scheff and Frierson, 2014; Roderick et al., 2014; Fu and Feng, 2014). In their analysis of CMIP5 Representative Concentration Pathway (RCP) 8.5 models, Scheff and Frierson (2014) approximate the rate of annual-mean $E_{P}$ increase per degree of warming as $\sim 1.5-4 \%$ globally, with lower (higher) values in warmer (cooler) climates. They estimate that in the western United States, $E_{P}$ scales with temperature at a rate of $\sim 1.8-2.8 \%$ across models, with a multi-model mean value of approximately $\sim 2.25 \%$ (Scheff and Frierson (2014) Figure 11). We use these ranges- $0.9-1.6 \%$ and $1.8 \%-2.8 \%$ for $R_{N}$ vs. T and $E_{P}$ vs. T respectively-to represent uncertainty. 

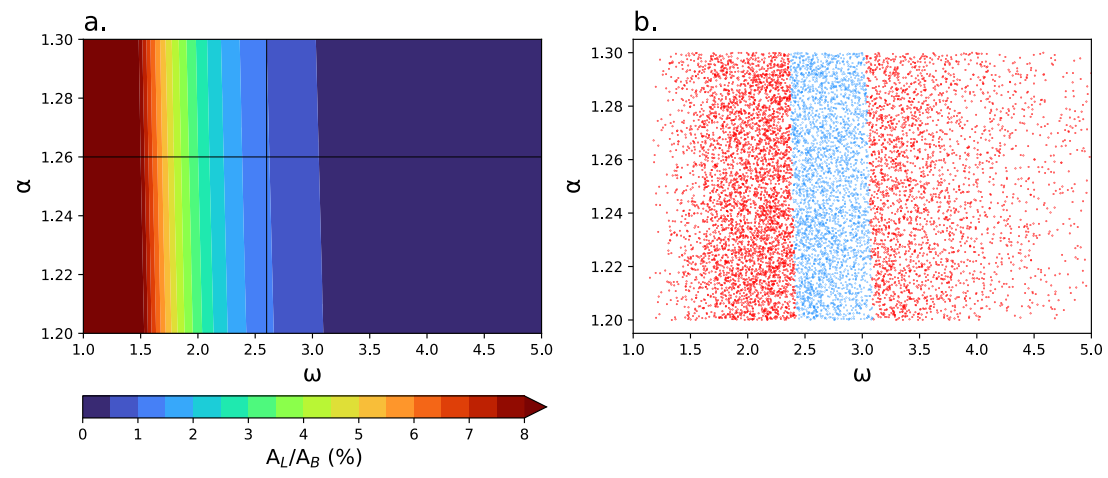

Figure 2: (a) Sensitivity of lake areas to variations in $\alpha$ and $\omega$. (b) $10^{4}$ samples of $(\omega, \alpha)$ combinations, sampling $\omega$ from the Greve et al. (2015) gamma distribution and $\alpha$ from a uniform distribution between 1.2-1.3. Blue points indicate combinations that produce modern $A_{L} / A_{B}$ between $0.5-1.5 \%$ of the South Great Basin.

\section{Results}

\subsection{Lake areas from proxies}

Our dry, intermediate, and wet scenarios yield lake areas $\left(A_{L} / A_{B}\right)$ of $1.4 \%$, $3.6 \%$, and $18.7 \%$, respectively. This range of areas suggests a slightly to much wetter water balance than the modern, where perennial lakes cover $0.5 \%$ of the basin and perennial and ephemeral lakes combined cover $1.5 \%$ of basin area. We note that our dry scenario does not unequivocally represent an absolute minimum; since some lakes are reconstructed from cores taken at a single location, it is possible that they could have recorded lakes with areas smaller than those included in our dry estimate. This is nevertheless unlikely given the presence of a number of perennial 3.2 Ma lakes in areas that are presently dry. In fact, our dry scenario is likely conservative, since 1) we omit Owens Lake despite Owens Valley being the probable source of water to the Coso and Searles Basins, which hosted lakes at 3.2 Ma, and 2) the estimate of lake area in Coso Basin is based on areal extent of outcropping Pliocene sediments, which are tilted and partly covered by younger sediments. Conversely, our wet scenario is likely generous, since it includes lakes that may not have existed at 3.2 Ma (potential lakes), and it assumes that all lake highstands occurred simultaneously. Further details of dating, lake area estimation, and paleoenvironment for each lake can be found in Table S1.

With our re-compilation effort, we find that the Pound et al. (2014) compilation of Pliocene lakes overestimates lake area in some regions and underestimates it in others. Specifically, Pound et al. (2014) include several lakes in the southern South Great Basin that only existed in the Pleistocene (e.g., Lake Manix), and omit perennial Pliocene lakes further north and east (e.g., Amargosa Marsh). Additionally, Mono Lake was previously double-counted as both 
Mono Lake and Lake Russell (the name given to the Pleistocene pluvial lake that existed in the Mono Basin). These discrepancies yield large differences in calculated lake area for the South Great Basin: the dry and wet scenarios from the Pound et al. (2014) compilation are $19.7 \%$ and $20.5 \%$, respectively.

\subsection{Forward modeling and comparison to climate models}

The observed Pliocene changes in $A_{L} / A_{B}$ could have been accomplished by a number of possible combinations of $\Delta T$ and $\Delta P$, and uncertainty in our proxy model parameters increases the spread of possibilities. To compare proxy and model results and illustrate the associated uncertainty, we take the following approach. For each combination of possible Pliocene changes in climatologicalmean surface temperature $(\Delta T)$ and precipitation $(\Delta P)$ shown in Figure 3 , we perform $10^{3}$ computations of Equation 2, each time selecting $\omega, \alpha, R_{N}$, and $E_{P}$ by sampling from the distributions of the regionally valid combinations of $\alpha$ and $\omega$ and from uniform distributions of the empirically-determined ranges of changes in $R_{N}(0.9-1.6 \%)$ and $E_{P}(1.8 \%-2.8 \%)$ with temperature. Over the space of $(\Delta T, \Delta P)$ we contour the mean values of $A_{L} / A_{B}$ from our MonteCarlo sampling (Figure 3). Additional contours of the 25th and 75th percentiles (thin solid), and of 5th and 95th percentiles (dotted), for each of the three scenarios illustrate the uncertainty introduced by the proxy-system model used to translate from $(\Delta T, \Delta P)$ in each climate model to $A_{L} / A_{B}$. The uncertainties in our proxy-system model are smaller than the uncertainties captured by the differences between dry, intermediate, and wet scenarios.

Pliocene minus pre-industrial $\Delta T$ and $\Delta P$ from those PlioMIP2 models with surface temperature and precipitation fields available are shown as colored dots in Figure 3 (See also Supplement Section 1.3 and Table S2). The multi-model mean, indicated by a star, best matches an $A_{L} / A_{B}$ value of $0.6 \%$. Assuming that the probable range of $\omega$ remains constant between the Pliocene and modern, as in Figure 3, the majority of PlioMIP2 models predict an $A_{L} / A_{B}$ in the South Great Basin lower than the dry scenario of our proxy compilation. Only three models-CESM2, COSMOS, and MIROC4m-fall between the 5th and 95th percentile contours for the dry scenario. None of the models falls within the 5th and 95th percentile contours for the intermediate scenario.

One caveat to this comparison is the possibility of a systematic change in $\omega$ across the Southern Great Basin region over time. However, $\omega$ would need to decrease to 2.1 for the multi-model mean $(\Delta T, \Delta P)$ to predict $A_{L} / A_{B}$ equal to the dry proxy scenario, and to 1.6 to equal the intermediate scenario (Figure S3 c-d). Could a widespread change in catchment conditions have driven such decreases in $\omega$ between the mid-Pliocene warm period and the pre-industrial? Vegetation reconstructions from 3.6-2.6 Ma (Molnar and Cane, 2007; Salzmann et al., 2008; Winnick et al., 2013) suggest expanded woodland and forest ecosystems in place of today's dry shrublands. If these records accurately capture conditions during the PRISM4 time-slice, one might expect greener and leafier vegetation, increased leaf area and photosynthetic rates, and consequently higher evapotranspiration resulting in increased $\omega$ values (Donohue 
et al., 2007; Roderick and Farquhar, 2011). Elevated $\mathrm{CO}_{2}$ has the effect of decreasing leaf transpiration per unit area, so may have the inverse effect and thus decrease $\omega$ in humid areas. In water-limited areas, however, leaf area per unit ground area also increases, in which case elevated $\mathrm{CO}_{2}$ would likely have little effect on $\omega$. (Roderick and Farquhar, 2011). Finally, more frequent fires or a more even distribution of precipitation across the domain or across seasons would increase $\omega$. On balance, known features of the mid-Pliocene world suggest an ambiguous, perhaps positive, influence on $\omega$-rather than the decrease in $\omega$ that would bring models into closer agreement with proxy reconstructions. It is therefore unlikely that a change in the range of $\omega$ values across the South Great Basin would narrow the discrepancy between $A_{L} / A_{B}$ indicated by our proxy compilation and by climate models.

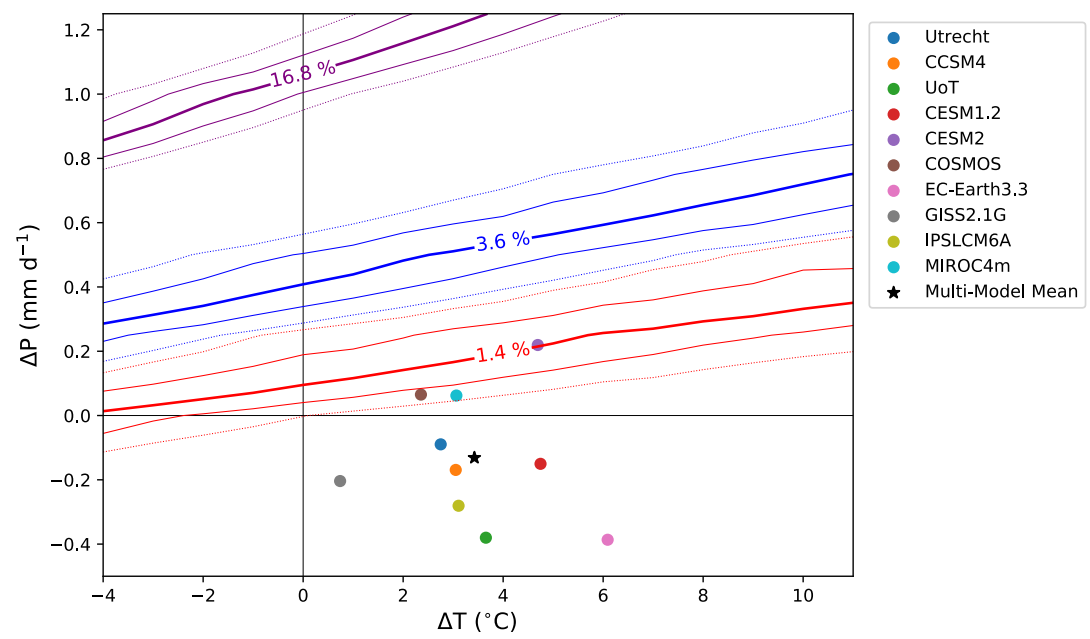

Figure 3: Contours of $A_{L} / A_{B}$ for the South Great Basin from our proxy compilation on corresponding Pliocene-pre-industrial changes in surface temperature and precipitation. Red, blue, and purple contours represent $A_{L} / A_{B}$ from our dry, intermediate, and wet scenarios respectively. Thick solid lines contour the mean, thin solid lines contour the 25 th and 75 th percentiles, and dotted lines contour the 5th and 95th percentiles. Colored dots mark $(\Delta \mathrm{T}, \Delta \mathrm{P})$ for each PlioMIP2 climate model, and the black star marks the multi-model mean.

\section{Discussion}

The considerable differences between our dry, intermediate, and wet scenarios interpreted from proxy records testify to remaining uncertainties in proxy reconstructions of the presence and extent of mid-Pliocene lakes. We highlight the need for additional high-resolution (sub-orbital scale) proxy records of midPliocene lakes, in particular from less complex regions of the domain considered here such as Fish Lake Valley, Clayton Valley, and Mono Basin. Nonetheless, only 
three PlioMIP2 climate models produce mid-Pliocene temperature and precipitation changes that fall within the $90 \%$ confidence interval of the dry scenario, and all fall well below the $90 \%$ confidence interval of the intermediate scenario. This indicates that uncertainties in the interpretation of proxy data, though substantial, are not solely responsible for model-data discrepancy in this region. Our analysis therefore suggests that even during the narrow KM5c interglacial time-slice, the water balance in the South Great basin was at least slightly wetter than models predict, and potentially much wetter.

From these results we draw two conclusions about model boundary conditions. First, and paradoxically, the widespread lakes used in PlioMIP2 boundary conditions (Pound et al., 2014) could not have existed under the dry conditions simulated by PlioMIP2 models themselves. This is both because the lakes used in the PRISM4 reconstruction are too large and numerous, particularly in the southern part of our study area (Figure S5), and also because the regional climate simulated by PlioMIP2 models is too dry (Figure 3). This inconsistency is notable not only from the perspective of model evaluation, but also because these boundary conditions can in turn impact the regional modeled climate.

Second, we speculate that errors in more remote boundary conditions may contribute to over-drying of the US Southwest. In the UofT-CCSM4 model, PlioMIP2 ice and orography boundary conditions trigger a wintertime stationary wave response that causes un-intuitive drying in the western United States (Menemenlis et al., 2021). Most other PlioMIP2 models also show winter-time drying in the South Great Basin (Figure S1), and may be subject to similar mechanisms. PlioMIP1, which used different boundary conditions from PlioMIP2, did not see drying in this region. Importantly, boundary conditions for ice and orography are themselves subject to large uncertainties. This warrants further refinement of the paleoenvironmental reconstructions used for ice sheet and topography boundary conditions, as well as further exploration of their impact on modeled midlatitude dynamics.

The KM5c marine isotope stage was selected as the time period within the mid-Pliocene most analogous to future climate because it experienced orbital forcing similar to present-day (Haywood et al., 2013a). In this time slice, climate models simulate drier conditions than indicated by proxy data. These proxy data, in turn, may be interpreted to suggest a water balance either similar to or much wetter than the present-day. It is therefore not obvious whether the mechanisms invoked to explain much wetter Pliocene conditions in this region-namely, tropical ocean feedbacks and teleconnections related to a permanent El Niño-like state-are accurate analogs for the dynamical response to future global warming. Uncertainties at all three corners of the PMIP triangle remain considerable. Co-ordinated advancements in terrestrial proxy reconstruction, experimental design, and climate modeling will make possible a more complete description of the regional hydroclimate response to mid-Pliocene warm period conditions. 


\section{Conclusions}

In the American Southwest, we compared mid-Pliocene warm period climate model output to lacustrine proxy records from the same period, with an emphasis on quantifying the uncertainties in the interpretation of proxy records. We assembled a refined compilation of proxy-recorded lakes, calculating areas for a conservative "dry", an "intermediate," and a generous "wet" scenario. We used a proxy-system modeling framework to directly compare between basinnormalized lake areas from our proxy compilations, and paleoclimate modelpredicted temperature and precipitation in the region. We found that most of the climate models simulate drier conditions than any of the three proxy-based scenarios, and that both models and proxies point to drier conditions in this region than previously thought. While these results cast doubt on the extent to which some analyses of the Pliocene hydrologic cycle are relevant to the narrow 3.204-3.207 Ma time slice targeted by PlioMIP2 models, we also highlight substantial remaining uncertainties in our picture of regional hydroclimate during this time.

\section{Acknowledgements}

This manuscript benefited from discussions with Jeff Knott and Marith Reheis about the geologic setting and history of South Great Basin Lakes. We thank the modeling groups involved in PlioMIP2 for making their output available though the Earth System Grid Federation and PlioMIP2 database.

\section{References}

Allen, R. G., Pereira, L. S., Raes, D., and Smith, M. (1998). Crop evapotranspiration: guidelines for computing crop water requirements. Number 56 in FAO irrigation and drainage paper. Food and Agriculture Organization of the United Nations, Rome.

Assouline, S., Li, D., Tyler, S., Tanny, J., Cohen, S., Bou-Zeid, E., Parlange, M., and Katul, G. G. (2016). On the variability of the Priestley-Taylor coefficient over water bodies. Water Resources Research, 52(1):150-163.

Brierley, C., Burls, N., Ravelo, C., and Fedorov, A. (2015). Pliocene warmth and gradients. Nature Geoscience, 8(6):419-420.

Brutsaert, W. (2005). Hydrology: An Introduction. Cambridge University Press, Cambridge.

Burls, N. J. and Fedorov, A. V. (2017). Wetter subtropics in a warmer world: Contrasting past and future hydrological cycles. Proceedings of the National Academy of Sciences, 114(49):12888-12893. 
Chan, W.-L. and Abe-Ouchi, A. (2020). Pliocene Model Intercomparison Project (PlioMIP2) simulations using the Model for Interdisciplinary Research on Climate (MIROC4m). Climate of the Past, 16(4):1523-1545.

Donohue, R. J., Roderick, M. L., and McVicar, T. R. (2007). On the importance of including vegetation dynamics in Budyko's hydrological model. Hydrology and Earth System Sciences, 11(2):983-995. Publisher: Copernicus GmbH.

Dowsett, H., Dolan, A., Rowley, D., Moucha, R., Forte, A. M., Mitrovica, J. X., Pound, M., Salzmann, U., Robinson, M., Chandler, M., Foley, K., and Haywood, A. (2016). The PRISM4 (mid-Piacenzian) paleoenvironmental reconstruction. Climate of the Past, 12(7):1519-1538.

Fedorov, A. V., Dekens, P. S., McCarthy, M., Ravelo, A. C., deMenocal, P. B., Barreiro, M., Pacanowski, R. C., and Philander, S. G. (2006). The Pliocene Paradox (Mechanisms for a Permanent El Niño). Science, 312(5779):14851489. Publisher: American Association for the Advancement of Science Section: Review.

Feng, R., Bhattacharya, T., Otto-bliesner, B., and Brady, E. (2021). MidPliocene mesic subtropical hydroclimate over continents driven by land surface changes. Technical Report EGU21-13907, Copernicus Meetings. Conference Name: EGU21.

$\mathrm{Fu}$, B. (1981). On the calculation of the evaporation from land surface [in Chinese]. Sci. Atmos. Sin., pages 23-31.

$\mathrm{Fu}, \mathrm{Q}$. and Feng, S. (2014). Responses of terrestrial aridity to global warming. Journal of Geophysical Research: Atmospheres, 119(13):7863-7875.

Goldner, A., Huber, M., Diffenbaugh, N., and Caballero, R. (2011). Implications of the Permanent El Niño Teleconnection "Blueprint" for Past Global and North American Hydroclimatology. Climate of the Past.

Greve, P., Gudmundsson, L., Orlowsky, B., and Seneviratne, S. I. (2015). Introducing a probabilistic Budyko framework. Geophysical Research Letters, 42(7):2261-2269.

Haywood, A. M., Dolan, A. M., Pickering, S. J., Dowsett, H. J., McClymont, E. L., Prescott, C. L., Salzmann, U., Hill, D. J., Hunter, S. J., Lunt, D. J., Pope, J. O., and Valdes, P. J. (2013a). On the identification of a Pliocene time slice for data-model comparison. Philosophical Transactions of the Royal Society A: Mathematical, Physical and Engineering Sciences, 371(2001):20120515.

Haywood, A. M., Dowsett, H. J., Dolan, A. M., Rowley, D., Abe-Ouchi, A., OttoBliesner, B., Chandler, M. A., Hunter, S. J., Lunt, D. J., Pound, M., and Salzmann, U. (2016). The Pliocene Model Intercomparison Project (PlioMIP) Phase 2: scientific objectives and experimental design. Climate of the Past, 12(3):663-675. 
Haywood, A. M., Hill, D. J., Dolan, A. M., Otto-Bliesner, B. L., Bragg, F., Chan, W.-L., Chandler, M. A., Contoux, C., Dowsett, H. J., Jost, A., Kamae, Y., Lohmann, G., Lunt, D. J., Abe-Ouchi, A., Pickering, S. J., Ramstein, G., Rosenbloom, N. A., Salzmann, U., Sohl, L., Stepanek, C., Ueda, H., Yan, Q., and Zhang, Z. (2013b). Large-scale features of Pliocene climate: results from the Pliocene Model Intercomparison Project. Climate of the Past, 9(1):191-209.

Haywood, A. M., Tindall, J. C., Dowsett, H. J., Dolan, A. M., Foley, K. M., Hunter, S. J., Hill, D. J., Chan, W.-L., Abe-Ouchi, A., Stepanek, C., Lohmann, G., Chandan, D., Peltier, W. R., Tan, N., Contoux, C., Ramstein, G., Li, X., Zhang, Z., Guo, C., Nisancioglu, K. H., Zhang, Q., Li, Q., Kamae, Y., Chandler, M. A., Sohl, L. E., Otto-Bliesner, B. L., Feng, R., Brady, E. C., von der Heydt, A. S., Baatsen, M. L. J., and Lunt, D. J. (2020). The Pliocene Model Intercomparison Project Phase 2: large-scale climate features and climate sensitivity. Climate of the Past, 16(6):2095-2123.

Haywood, A. M., Valdes, P. J., and Sellwood, B. W. (2002). Magnitude of climate variability during middle Pliocene warmth: a palaeoclimate modelling study. Palaeogeography, Palaeoclimatology, Palaeoecology, 188(1):1-24.

Ibarra, D. E., Oster, J. L., Winnick, M. J., Caves Rugenstein, J. K., Byrne, M. P., and Chamberlain, C. P. (2018). Warm and cold wet states in the western United States during the Pliocene-Pleistocene. Geology, 46(4):355-358.

Knott, J. R., Machette, M. N., Wan, E., Klinger, R. E., Liddicoat, J. C., SarnaWojcicki, A. M., Fleck, R. J., Deino, A. L., Geissman, J. W., Slate, J. L., Wahl, D. B., Wernicke, B. P., Wells, S. G., Tinsley, J. C., Hathaway, J. C., and Weamer, V. M. (2018). Late Neogene-Quaternary tephrochronology, stratigraphy, and paleoclimate of Death Valley, California, USA. GSA Bulletin, 130(7-8):12311255 .

Knott, J. R., Wan, E., Deino, A. L., Casteel, M., Reheis, M. C., Phillips, F. M., Walkup, L., McCarty, K., Manoukian, D. N., and Nunez, E. (2019). Lake Andrei: A Pliocene pluvial lake in Eureka Valley, eastern California.

Menemenlis, S., Lora, J. M., Lofverstrom, M., and Chandan, D. (2021). Influence of stationary waves on mid-Pliocene atmospheric rivers and hydroclimate. Global and Planetary Change, 204:103557.

Milly, P. C. D. and Dunne, K. A. (2016). Potential evapotranspiration and continental drying. Nature Climate Change, 6(10):946-949. Number: 10 Publisher: Nature Publishing Group.

Mix, H. T., Caves Rugenstein, J. K., Reilly, S. P., Ritch, A. J., Winnick, M. J., Kukla, T., and Chamberlain, C. P. (2019). Atmospheric flow deflection in the late Cenozoic Sierra Nevada. Earth and Planetary Science Letters, 518:76-85.

Molnar, P. and Cane, M. A. (2007). Early Pliocene (pre-Ice Age) El Niño-like global climate: Which El Niño? Geosphere, 3(5):337-365. 
Oldeman, A. M., Baatsen, M. L. J., von der Heydt, A. S., Dijkstra, H. A., Tindall, J. C., Abe-Ouchi, A., Booth, A. R., Brady, E. C., Chan, W.-L., Chandan, D., Chandler, M. A., Contoux, C., Feng, R., Guo, C., Haywood, A. M., Hunter, S. J., Kamae, Y., Li, Q., Li, X., Lohmann, G., Lunt, D. J., Nisancioglu, K. H., Otto-Bliesner, B. L., Peltier, W. R., Pontes, G. M., Ramstein, G., Sohl, L. E., Stepanek, C., Tan, N., Zhang, Q., Zhang, Z., Wainer, I., and Williams, C. J. R. (2021). Reduced El Niño variability in the mid-Pliocene according to the PlioMIP2 ensemble. Climate of the Past Discussions, pages 1-35. Publisher: Copernicus GmbH.

O’Brien, C. L., Foster, G. L., Martínez-Botí, M. A., Abell, R., Rae, J. W. B., and Pancost, R. D. (2014). High sea surface temperatures in tropical warm pools during the Pliocene. Nature Geoscience, 7(8):606-611.

Pound, M., Tindall, J., Pickering, S., Haywood, A., Dowsett, H., and Salzmann, U. (2014). Late Pliocene lakes and soils: a global data set for the analysis of climate feedbacks in a warmer world. Climate of the Past, 10(1):167-180.

Prescott, C. L., Haywood, A. M., Dolan, A. M., Hunter, S. J., Pope, J. O., and Pickering, S. J. (2014). Assessing orbitally-forced interglacial climate variability during the mid-Pliocene Warm Period. Earth and Planetary Science Letters, 400:261-271.

Priestley, C. H. B. and Taylor, R. J. (1972). On the Assessment of Surface Heat Flux and Evaporation Using Large-Scale Parameters. Monthly Weather Review, 100(2):81-92. Publisher: American Meteorological Society Section: Monthly Weather Review.

Ravelo, A. C., Lawrence, K. T., Fedorov, A., and Ford, H. L. (2014). Comment on "A 12-million-year temperature history of the tropical Pacific Ocean". Science, 346(6216):1467.1-1467.

Reheis, M. C., Adams, K. D., Oviatt, C. G., and Bacon, S. N. (2014). Pluvial lakes in the Great Basin of the western United States-a view from the outcrop. Quaternary Science Reviews, 97:33-57.

Roderick, M. L. and Farquhar, G. D. (2011). A simple framework for relating variations in runoff to variations in climatic conditions and catchment properties. Water Resources Research, 47(12).

Roderick, M. L., Sun, F., Lim, W. H., and Farquhar, G. D. (2014). A general framework for understanding the response of the water cycle to global warming over land and ocean. Hydrol. Earth Syst. Sci., page 15.

Salzmann, U., Dolan, A. M., Haywood, A. M., Chan, W.-L., Voss, J., Hill, D. J., Abe-Ouchi, A., Otto-Bliesner, B., Bragg, F. J., Chandler, M. A., Contoux, C., Dowsett, H. J., Jost, A., Kamae, Y., Lohmann, G., Lunt, D. J., Pickering, S. J., Pound, M. J., Ramstein, G., Rosenbloom, N. A., Sohl, L., Stepanek, 
C., Ueda, H., and Zhang, Z. (2013). Challenges in quantifying Pliocene terrestrial warming revealed by data-model discord. Nature Climate Change, 3(11):969-974.

Salzmann, U., Haywood, A. M., Lunt, D. J., Valdes, P. J., and Hill, D. J. (2008). A new global biome reconstruction and data-model comparison for the Middle Pliocene. Global Ecology and Biogeography, 17(3):432-447.

Scheff, J. and Frierson, D. M. W. (2014). Scaling Potential Evapotranspiration with Greenhouse Warming. Journal of Climate, 27(4):1539-1558. Publisher: American Meteorological Society Section: Journal of Climate.

Seager, R., Osborn, T. J., Kushnir, Y., Simpson, I. R., Nakamura, J., and Liu, H. (2019). Climate Variability and Change of Mediterranean-Type Climates. Journal of Climate, 32(10):2887-2915. Publisher: American Meteorological Society Section: Journal of Climate.

Seager, R. and Vecchi, G. A. (2010). Greenhouse warming and the 21st century hydroclimate of southwestern North America. Proceedings of the National Academy of Sciences, 107(50):21277-21282.

Tierney, J. E., Haywood, A. M., Feng, R., Bhattacharya, T., and Otto-Bliesner, B. L. (2019). Pliocene Warmth Consistent With Greenhouse Gas Forcing. Geophysical Research Letters, 46(15):9136-9144.

Tierney, J. E., Poulsen, C. J., Montañez, I. P., Bhattacharya, T., Feng, R., Ford, H. L., Hönisch, B., Inglis, G. N., Petersen, S. V., Sagoo, N., Tabor, C. R., Thirumalai, K., Zhu, J., Burls, N. J., Foster, G. L., Goddéris, Y., Huber, B. T., Ivany, L. C., Turner, S. K., Lunt, D. J., McElwain, J. C., Mills, B. J. W., Otto-Bliesner, B. L., Ridgwell, A., and Zhang, Y. G. (2020). Past climates inform our future. Science, 370(6517).

Wara, M. W., Ravelo, A. C., and Delaney, M. L. (2005). Permanent El Nino-Like Conditions During the Pliocene Warm Period. Science, 309(5735):758-761.

White, S. M. and Ravelo, A. C. (2020). Dampened El Niño in the Early Pliocene Warm Period. Geophysical Research Letters, 47(4):e2019GL085504.

Willeit, M., Ganopolski, A., and Feulner, G. (2013). On the effect of orbital forcing on mid-Pliocene climate, vegetation and ice sheets. Accepted: 201808-29T00:06:51Z Publisher: München : European Geopyhsical Union.

Williams, A. P., Cook, E. R., Smerdon, J. E., Cook, B. I., Abatzoglou, J. T., Bolles, K., Baek, S. H., Badger, A. M., and Livneh, B. (2020). Large contribution from anthropogenic warming to an emerging North American megadrought. Science, 368(6488):314-318. Publisher: American Association for the Advancement of Science Section: Report. 
Winnick, M. J., Welker, J. M., and Chamberlain, C. P. (2013). Stable isotopic evidence of El Niño-like atmospheric circulation in the Pliocene western United States. Climate of the Past, 9(2):903-912.

Wycech, J. B., Gill, E., Rajagopalan, B., Marchitto, T. M., and Molnar, P. H. (2020). Multiproxy Reduced-Dimension Reconstruction of Pliocene Equatorial Pacific Sea Surface Temperatures. Paleoceanography and Paleoclimatology, 35(1):e2019PA003685.

Zhang, L., Hickel, K., Dawes, W. R., Chiew, F. H. S., Western, A. W., and Briggs, P. R. (2004). A rational function approach for estimating mean annual evapotranspiration. Water Resources Research, 40(2).

Zhang, Y. G., Pagani, M., and Liu, Z. (2014). A 12-Million-Year Temperature History of the Tropical Pacific Ocean. Science, 344(6179):84-87. Publisher: American Association for the Advancement of Science Section: Report. 
Supplement to "A proxy-model comparison for mid-Pliocene warm period hydroclimate in the Southwestern US"

Sofia Menemenlis ${ }^{1}$, Sarah M. White ${ }^{2}$, Daniel E. Ibarra ${ }^{3,4}$, Juan M. Lora ${ }^{1}$

${ }^{1}$ Dept. of Earth and Planetary Sciences, Yale University, New Haven, CT

${ }^{2}$ Dept. of Geography, UC Berkeley, Berkeley, $C A$

${ }^{3}$ Dept. of Earth and Planetary Science, UC Berkeley, Berkeley, CA

${ }^{4}$ Dept. of Earth, Environmental, and Planetary Sciences and the Institute at Brown for

Environment and Society, Brown University, Providence, RI

Contents:

1. Supplementary text

1.1. Defining the South Great Basin boundary

1.2. Finding modern lake areas

1.3. Reanalysis and paleoclimate model data

2. Supplementary figures

3. Supplementary tables

4. References 


\section{Supplementary text}

\subsection{Defining the South Great Basin boundary}

The South Great Basin perimeter is defined by the outer boundaries of inwardly-draining basins from the HydroBASINS database (Lehner and Grill, 2013; available from hydrosheds.org). At the northeastern boundary of the basin, we include a sub-region of an adjacent basin, since in this area a recent USGS groundwater model (Brooks et al., 2014) predicts subsurface water to flow toward Clayton Valley, where one of our Pliocene proxy sites is located (see Figure 1 in main text).

\subsection{Finding modern lake areas}

We draw on published maps, crowdsourced Open Street Map data(Open Street Map, 2021; Open Street Map data copyrighted OpenStreetMap contributors and available from openstreetmap.org), and Google satellite imagery (Google, 2021; Google Satellite Imagery (C)2021 TerraMetrics, Map data (C)2021Google) to produce GIS shapefiles of modern perennial and seasonal lakes in the South Great Basin. The two largest modern perennial lakes are Mono Lake and Owens Lake. Although Owens Lake is dry today, it existed perennially until the 1920s, when the city of Los Angeles diverted water for human use (Reheis, 1997; Smith and StreetPerrott, 1983). There are also a number of smaller perennial lakes on the western side of the South Great Basin. Smith (1984) mapped present-day lakes and seasonal playas; we use their Figure 1 as an initial reference for the locations of seasonal playas, then trace more precise shapes using Open Street Map and Google satellite data. In addition to those mapped in Smith (1984), we include several additional playas known to contain water on a seasonal basis.

\subsection{Reanalysis and paleoclimate model data}

MERRA2 reanalysis data (Gelaro et al., 2017) is available at disc.gsfc.nasa.gov. We use precipitation, skin temperature, surface radiation, and topography fields from the following datasets: "MERRA-2 const_2d_asm_Nx: 2d, constants V5.12.4", "MERRA-2 tavg1_2d_flx_Nx: 2d,1-Hourly,Time-Averaged,Single-Level,Assimilation,Surface Flux Diagnostics V5.12.4", and "MERRA-2 tavg1 2d rad Nx: 2d,1-Hourly,Time-Averaged,SingleLevel,Assimilation, Radiation Diagnostics V5.12.4" (GMAO, 2015a-c). MERRA2 corrects modeled precipitation with observational land surface precipitation data (Reichle et al., 2017). This approach also lessens bias in surface radiation terms as precipitation affects the partitioning between sensible and latent heating, particularly in areas where surface latent heating is moisture-limited (Draper et al., 2018).

We use output from 10 models participating in the Paleoclimate Model Intercomparison Project, Version 2 (PlioMIP2, Haywood et al. 2020). The modeling groups have archived monthly output for precipitation and surface temperature at the PlioMIP2 data repository at the University of Leeds. To find Pliocene minus pre-industrial anomalies in precipitation and surface temperature, we took the difference between the "Eoi400" and "E280" runs for each model. For additional detail regarding PlioMIP2 boundary conditions, experimental design, and results, see Dowsett et al. (2016), Haywood et al. (2016), and Haywood et al. (2020). For a summary of and references to the models used in this study, see Table S2.

For consistency, we interpolate all reanalysis and paleoclimate model data to a uniform $0.25^{\circ}$ latitude by $0.25^{\circ}$ longitude grid. Note that the PlioMIP2 models were run with different spatial resolutions (Table S2). 


\section{Supplementary figures}
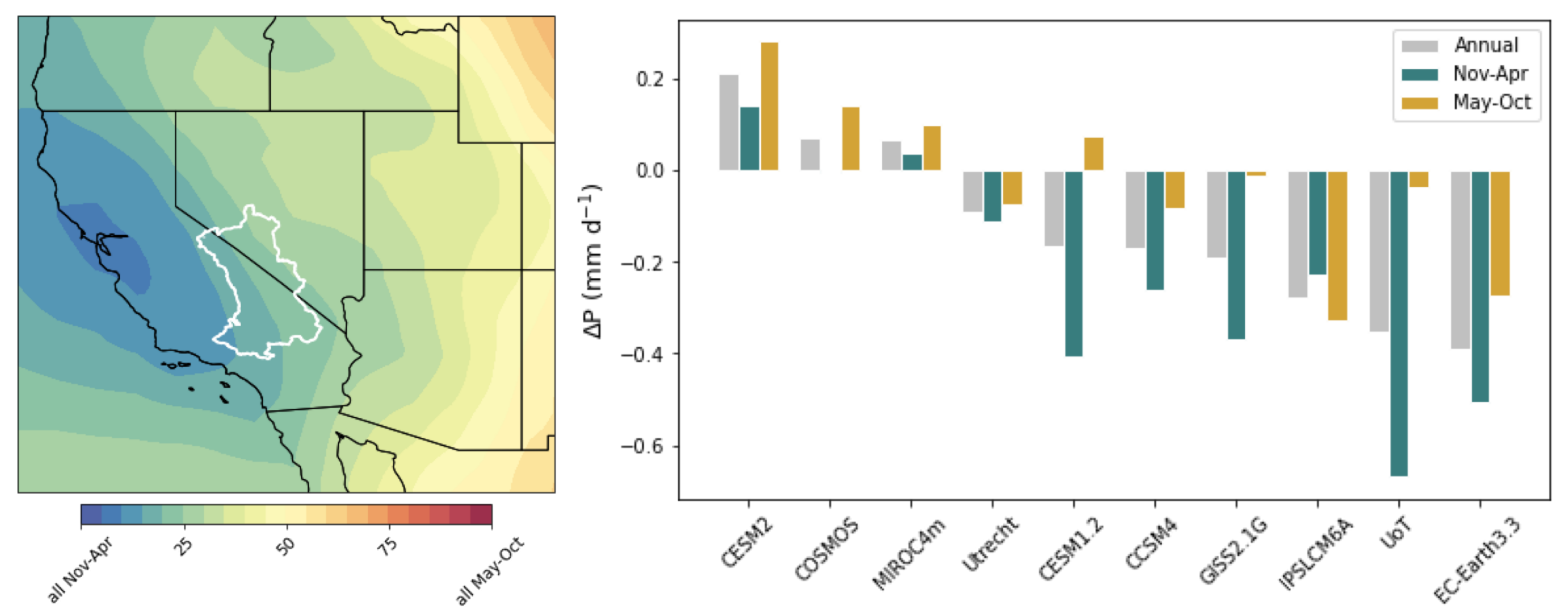

Figure S1. Contours: seasonality of precipitation in multi-model-mean pre-industrial simulations. Colors indicate the percent contribution of warm-season (May-October) precipitation to the annual-mean. Bar graph: Pliocene minus pre-industrial precipitation for the South Great Basin, annually and for each half-year, for each PlioMIP2 model used in our study.

a.

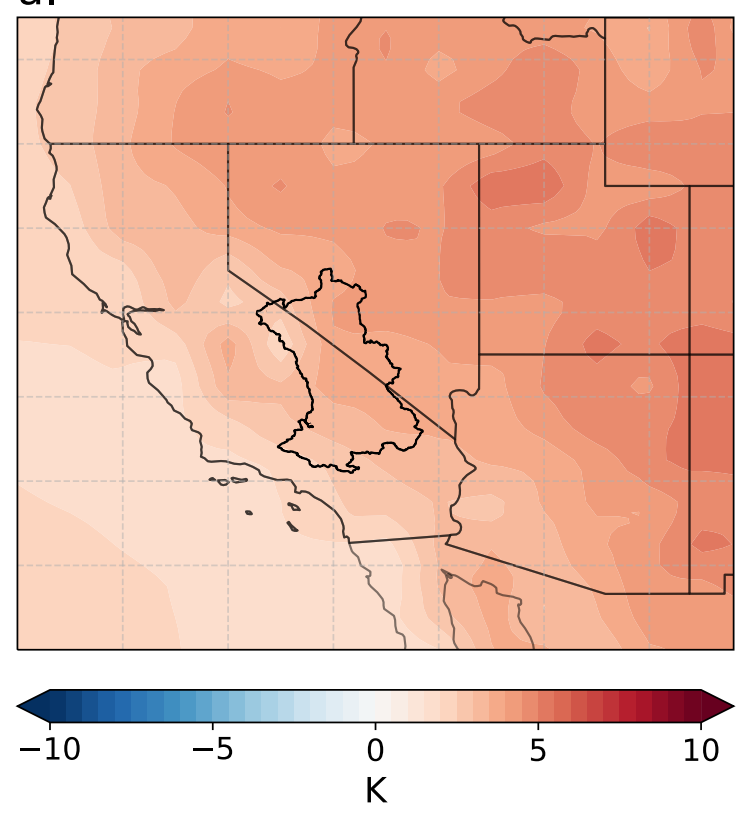

b.

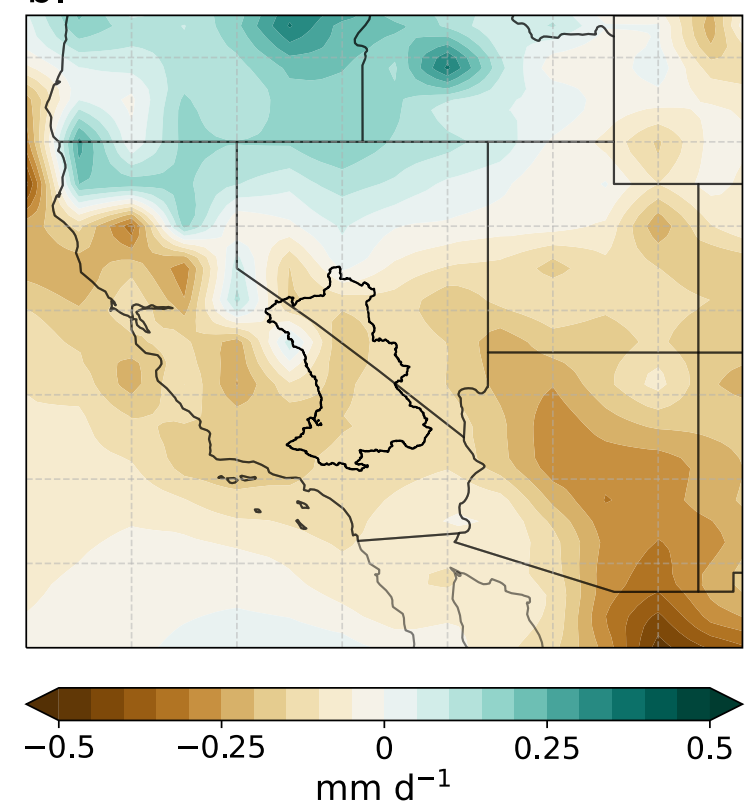

Figure S2. Pliocene minus pre-industrial change in (a) surface temperature, and (b) precipitation, for the ensemble mean of the models used in our analysis. 

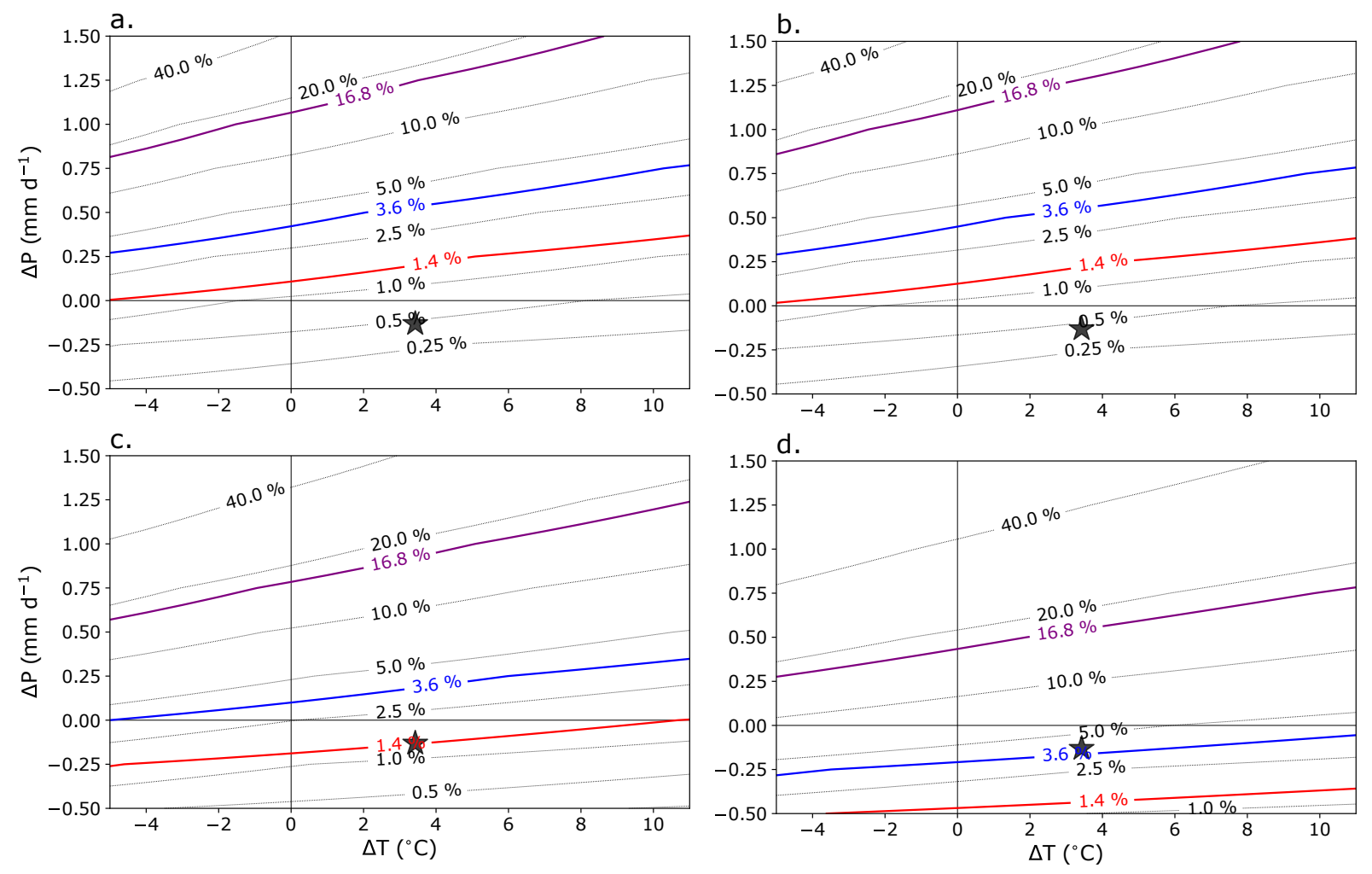

Figure S3. (a) Contour plot of South Great Basin lake areas calculated using the following parameters: $R_{N} / T=1.25 \% / \mathrm{K}, E_{P} / T=2.3 \% / \mathrm{K}, \omega=2.7, \alpha=1.25$. (b) Same as (a), but but incorporating the on evaporation (via the psychrometric constant, Equation 5 in main text) of increasing Pliocene elevations by 1000 m against modern. (b) Same as (a), but with $\omega=2.1$. This is the $\omega$ value at which the multi-model mean $(\Delta \mathrm{T}, \Delta \mathrm{P})$ would correspond with the dry proxy scenario. (c) Same as (a), but with $\omega=1.6$. This is the $\omega$ value at which the multi-model mean $(\Delta \mathrm{T}, \Delta \mathrm{P})$ would correspond with the intermediate proxy scenario. 


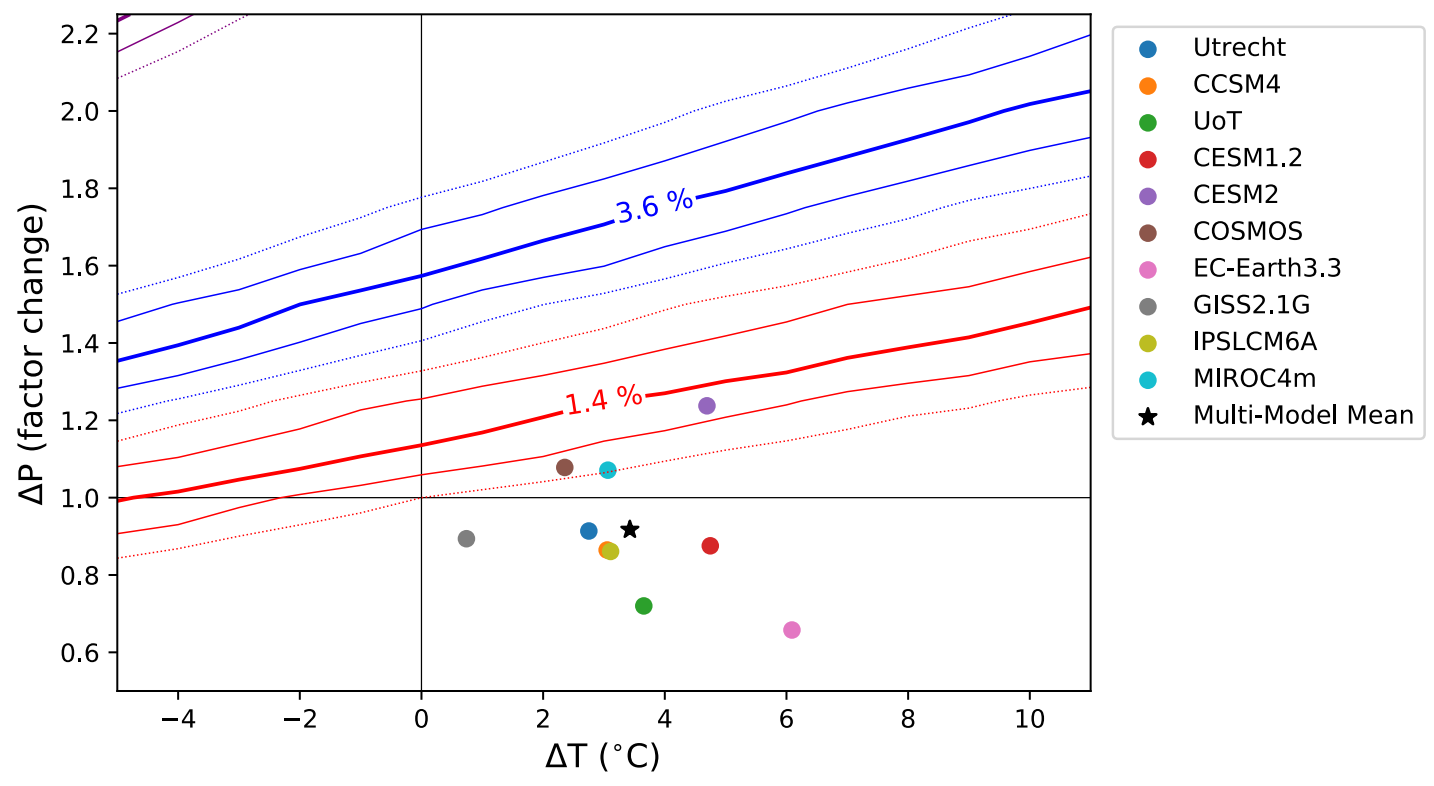

Figure S4. Similar to Figure 3, but adjusting precipitation by a scaling factor rather than by absolute values. Analogous to modeling results presented by Ibarra et al. (2018). 
a.

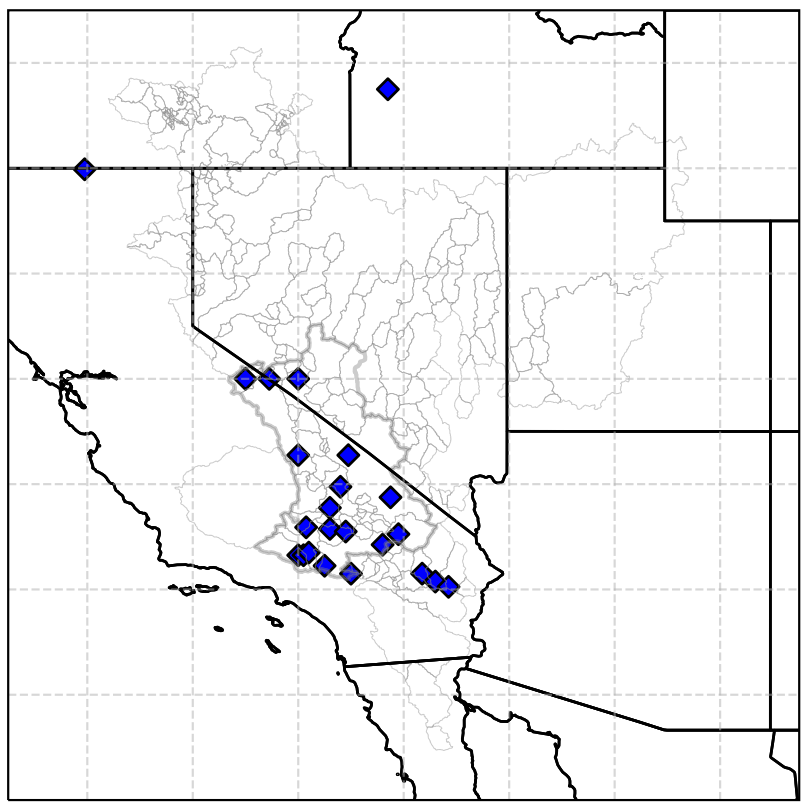

b.

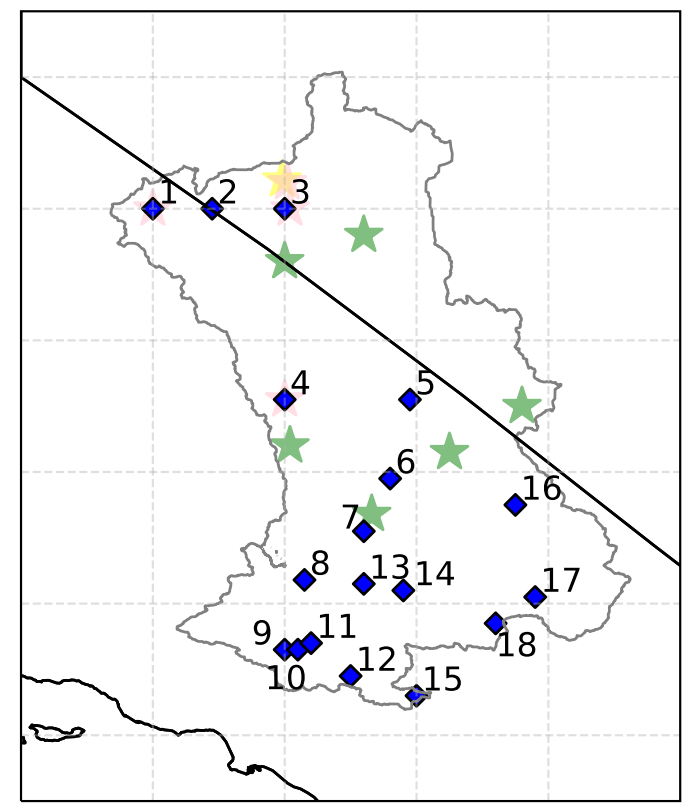

Figure S5. Blue diamonds indicate proxy locations from Pound et al. (2014). From (b): (1) Lake Russel (2) Mono Lake (3) Rhodes-Clayton-Fish Valleys, NV (4) Owens Lake (5) Lake Manly (6) Panamint Lake (7) China-Searles lake (8) Kochn Lake 1 (9) Harper 1 (10) Harper 2 (11) Harper 3 (12) Harper 4 (13) Kochn Lake 2 (14) Kochn Lake 3 (15) South Mojave (16) Lake Tecopa (17) Lake Mojave (18) Lake Manix. Stars show our proxy sites as in Figure 1 in the main text. 


\section{Supplementary tables}

Table S1. South Great Basin lake areas from proxies. Dates based on paleomagnetic data are updated to the most recent paleomagnetic timescale (Gradstein et al., 2012), and dates based on correlations to known tephras are updated to the most recent ages (Knott et al., 2018). Minimum lake areas are not calculated for potential or ephemeral lakes, since they are only included in the wet map. "Sed."=sediment, "correl."=correlated, 'paleomag.'=paleomagnetic data. Ages based on extrapolation assume a constant sedimentation rate from some datum to the bottom of basin fill, determined from geophysical data. Ages of tuffs: Bishop Tuff=0.772 +/- 0.008 Ma, Huckleberry Ridge Tuff=2.101 +/- 0.007 Ma, Putah Tuff=3.31 Ma, Mesquite Springs=3.32 Ma, Zabriskie Wash=3.335 +/- 0.002 Ma (Knott et al., 2018). Ages of paleomagnetic subchrons and transitions: Kaena=3.032-3.116 Ma, Mammoth=3.207-3.330 Ma, Gauss-Gilbert=3.596 MA (Ogg et al., 2012). NALMA = North American Land Mammal Ages, based on widely recognized type fossils. Most recent timescale from Bell et al. (2004). Hemphillian/Blancan boundary=4.6-5.2 Ma (Bell et al., 2004), 4.98-5.0 in eastern NV (Lindsay et al., 2002). Top of Blancan=2.5-1.9 Ma (Bell et al., 2004).

\begin{tabular}{|c|c|c|c|c|c|c|c|c|c|c|c|c|c|}
\hline Site name & Category & $\begin{array}{l}\text { Age } \\
\text { min } \\
\text { (Ma) }\end{array}$ & $\begin{array}{l}\text { Age } \\
\text { max } \\
\text { (Ma) }\end{array}$ & Lat & Lon & $\begin{array}{l}\text { Lake } \\
\text { area } \\
\left(\mathrm{km}^{2}\right)\end{array}$ & $\begin{array}{l}\text { Min } \\
\text { lake } \\
\text { area } \\
\left(\mathbf{k m}^{2}\right)\end{array}$ & $\begin{array}{l}\text { Modern } \\
\text { setting, } \\
\text { proxy } \\
\text { record } \\
\text { type }\end{array}$ & $\begin{array}{l}\text { Lake setting, } \\
\text { stratigraphy, } \\
\text { etc. }\end{array}$ & $\begin{array}{l}\text { Basis for } \\
\text { categorization }\end{array}$ & $\begin{array}{l}\text { Age } \\
\text { constraints }\end{array}$ & $\begin{array}{l}\text { Reference } \\
\text { for ages } \\
\text { and lake } \\
\text { setting }\end{array}$ & $\begin{array}{l}\text { Reference } \\
\text { for lake area }\end{array}$ \\
\hline $\begin{array}{l}\text { Redlich } \\
\text { Summit }\end{array}$ & $\begin{array}{l}\text { Ephemeral } \\
\text { lake }\end{array}$ & 2 & 6 & $\begin{array}{l}38.2 \\
2\end{array}$ & -118 & 9687 & & $\begin{array}{l}\text { Dry; } \\
\text { outcrops }\end{array}$ & $\begin{array}{l}\text { Modern divide } \\
\text { between } \\
\text { Columbus and } \\
\text { Rhodes Salt } \\
\text { Marshes. } \\
\text { Pliocene lake } \\
\text { sed: green } \\
\text { mudstone, } \\
\text { deltaic } \\
\text { sandstone, } \\
\text { diatomaceous } \\
\text { siltstone, } \\
\text { nearshore } \\
\text { sandstone. }\end{array}$ & $\begin{array}{l}\text { At least two } \\
\text { desiccation } \\
\text { surfaces } \\
\text { indicate lake } \\
\text { was ephemeral. }\end{array}$ & $\begin{array}{l}\text { Interbedded } \\
\text { tephra } \\
\text { correl. to } \\
\text { those at } 5.9 \\
\text { Ma and 2.2- } \\
2.5 \mathrm{Ma} \text {, } \\
\text { diatom } \\
\text { assemblages }\end{array}$ & $\begin{array}{l}\text { Reheis et } \\
\text { al., } 2002\end{array}$ & $\begin{array}{l}\text { Pound et al., } \\
2014 \text { (area of } \\
\text { their } \\
\text { "Rhodes- } \\
\text { Clayton- } \\
\text { Fish" valley, } \\
\text { minus areas } \\
\text { of Clayton } \\
\text { Valley and } \\
\text { Fish Lakes) }\end{array}$ \\
\hline $\begin{array}{l}\text { Columbus } \\
\text { Salt } \\
\text { Marsh }\end{array}$ & $\begin{array}{l}\text { Potential } \\
\text { lake }\end{array}$ & 0 & 7.8 & 38 & -118 & & & $\begin{array}{l}\text { Playa; } \\
\text { sed. core } \\
\text { and } \\
\text { geophys. } \\
\text { data }\end{array}$ & $\begin{array}{l}\text { If Redlich } \\
\text { Summit was } \\
\text { wet, then } \\
\text { Columbus Salt } \\
\text { Marsh was } \\
\text { also wet }\end{array}$ & $\begin{array}{l}\text { Unclear if lake } \\
\text { existed during } \\
\text { KM5c; lake } \\
\text { inferred from } \\
\text { geophys. data, } \\
\text { extrapolation, } \\
\text { and lake at }\end{array}$ & $\begin{array}{l}\text { Extrapolatio } \\
\mathrm{n} \text { (Bishop } \\
\text { Tuff to } \\
\text { bottom of } \\
\text { basin fill) }\end{array}$ & $\begin{array}{l}\text { Uranium } \\
\text { Resources } \\
\text { Inc. report, } \\
\text { Reheis et } \\
\text { al.,2002 }\end{array}$ & $\begin{array}{l}\text { Counted with } \\
\text { Redlich } \\
\text { Summit }\end{array}$ \\
\hline
\end{tabular}




\begin{tabular}{|c|c|c|c|c|c|c|c|c|c|c|c|c|c|}
\hline & & & & & & & & & & $\begin{array}{l}\text { Redlich } \\
\text { Summit }\end{array}$ & & & \\
\hline $\begin{array}{l}\text { Rhodes } \\
\text { Salt } \\
\text { Marsh }\end{array}$ & $\begin{array}{l}\text { Potential } \\
\text { Lake }\end{array}$ & 2 & 6 & 38.2 & -118 & & & $\begin{array}{l}\text { Brine } \\
\text { pools; } \\
\text { outcrops }\end{array}$ & $\begin{array}{l}\text { If Redlich } \\
\text { Summit was } \\
\text { wet, then } \\
\text { Rhodes Salt } \\
\text { Marsh was } \\
\text { also wet. } \\
\text { Limited } \\
\text { outcrops of } \\
\text { lake sediments } \\
\text { are similar to } \\
\text { Redlich } \\
\text { Summit. }\end{array}$ & $\begin{array}{l}\text { Unclear if lake } \\
\text { existed during } \\
\text { KM5c; detailed } \\
\text { regional } \\
\text { stratigraphy is } \\
\text { lacking, few } \\
\text { outcrops }\end{array}$ & $\begin{array}{l}\text { Shared } \\
\text { tephras with } \\
\text { Redlich } \\
\text { Summit }\end{array}$ & $\begin{array}{l}\text { Reheis et } \\
\text { al., } 2002\end{array}$ & $\begin{array}{l}\text { Counted with } \\
\text { Redlich } \\
\text { Summit }\end{array}$ \\
\hline $\begin{array}{l}\text { Mono } \\
\text { Lake }\end{array}$ & $\begin{array}{l}\text { Potential } \\
\text { Lake }\end{array}$ & 0 & 4 & 38 & -119 & 1125 & & $\begin{array}{l}\text { Lake; } \\
\text { outcrops }\end{array}$ & $\begin{array}{l}\text { Volcanically } \\
\text { active basin } \\
\text { since } 4 \text { Ma. } \\
\text { Pliocene lake } \\
\text { sed: diatomite, } \\
\text { oolitic sand, } \\
\text { fine-grained } \\
\text { sand and silt, } \\
\text { with } \\
\text { freshwater } \\
\text { fish, } \\
\text { gastropods, } \\
\text { mollusks, } \\
\text { microfossils, } \\
\text { and a few } \\
\text { mammals. }\end{array}$ & $\begin{array}{l}\text { Unclear if lake } \\
\text { existed during } \\
\text { KM5c; dates } \\
\text { are old with } \\
\text { large } \\
\text { uncertainty, } \\
\text { detailed } \\
\text { stratigraphy is } \\
\text { lacking. }\end{array}$ & $\begin{array}{l}\text { Fish } \\
\text { correlated to } \\
\text { Pliocene } \\
\text { Glenns } \\
\text { Ferry Fm., } \\
\text { K-Ar ages } \\
\text { on volcanics } \\
\text { at/near top } \\
\text { of lake } \\
\text { sediments } \\
\text { (3.3 Ma, 3.4 } \\
\text { Ma, 3.6 Ma) }\end{array}$ & $\begin{array}{l}\text { Gilbert et } \\
\text { al., } 1968 \\
\text { (volcanics) } \\
\text {; Miller } \\
\text { and Smith } \\
1981 \text { (fish) }\end{array}$ & $\begin{array}{l}\text { Pound et al., } \\
2014\end{array}$ \\
\hline $\begin{array}{l}\text { Clayton } \\
\text { Valley }\end{array}$ & $\begin{array}{l}\text { Perennial } \\
\text { lake }\end{array}$ & 1.8 & 3.4 & 37.8 & -117 & 663 & 90 & $\begin{array}{l}\text { Small } \\
\text { playa } \\
\text { before } \\
\text { mining; } \\
\text { outcrops, } \\
\text { sed. } \\
\text { cores }\end{array}$ & $\begin{array}{l}\text { Most } \\
\text { paleoenvironm } \\
\text { ental } \\
\text { information is } \\
\text { from sed. } \\
\text { cores. Pliocene } \\
\text { lake sed: green } \\
\text { clay with } \\
\text { organic-rich } \\
\text { layers, fine to } \\
\text { coarse silt and } \\
\text { sand, rare } \\
\text { halite. }\end{array}$ & $\begin{array}{l}\text { Evidence of } \\
\text { lacustrine } \\
\text { conditions } \\
\text { continuously } \\
\text { through the } \\
\text { mid-Pliocene. }\end{array}$ & $\begin{array}{l}\text { Extrapolatio } \\
\mathrm{n} \text { (Bishop } \\
\text { Tuff and } \\
\text { Huckleberry } \\
\text { Ridge tuff } \\
\text { to bottom of } \\
\text { basin fill) }\end{array}$ & $\begin{array}{l}\text { Coffey et } \\
\text { al., in } \\
\text { review }\end{array}$ & $\begin{array}{l}\text { Rush } 1968 \\
\text { report; min } \\
\text { from modern } \\
\text { playa }\end{array}$ \\
\hline
\end{tabular}




\begin{tabular}{|c|c|c|c|c|c|c|c|c|c|c|c|c|c|}
\hline $\begin{array}{l}\text { Fish Lake } \\
\text { Valley }\end{array}$ & $\begin{array}{l}\text { Perennial } \\
\text { lake }\end{array}$ & 2.85 & 3.4 & 37.6 & -118 & 450 & 188 & $\begin{array}{l}\text { Small } \\
\text { playa; } \\
\text { outcrop }\end{array}$ & $\begin{array}{l}\text { Part of the } \\
\text { modern } \\
\text { drainage to } \\
\text { Columbus Salt } \\
\text { Marsh. } \\
\text { Pliocene lake } \\
\text { sed: } \\
\text { gypsiferous } \\
\text { green } \\
\text { mudstone, } \\
\text { siltstone, } \\
\text { sandstone, } \\
\text { conglomerate. }\end{array}$ & $\begin{array}{l}\text { Evidence of } \\
\text { lacustrine } \\
\text { conditions } \\
\text { continuously } \\
\text { through the } \\
\text { mid-Pliocene }\end{array}$ & $\begin{array}{l}\text { Interbedded } \\
\text { tephra } \\
\text { correl. To } \\
\text { Zabriskie } \\
\text { Wash and } \\
\text { Putah Tuffs, } \\
\text { paleomag. } \\
\text { (Kaena and } \\
\text { Mammoth } \\
\text { subchrons) }\end{array}$ & $\begin{array}{l}\text { Reheis et } \\
\text { al., 1991; } \\
\text { Reheis et } \\
\text { al., 2002; } \\
\text { updated } \\
\text { tephra } \\
\text { correlation } \\
\text { s and ages } \\
\text { from Knott } \\
\text { et al., } 2019\end{array}$ & $\begin{array}{l}\text { Reheis et al., } \\
\text { 1993; min } \\
\text { from modern } \\
\text { playa }\end{array}$ \\
\hline $\begin{array}{l}\text { Owens } \\
\text { Lake }\end{array}$ & $\begin{array}{l}\text { Potential } \\
\text { lake }\end{array}$ & 0.8 & 4.5 & $\begin{array}{l}36.5 \\
5\end{array}$ & -118 & 1500 & & $\begin{array}{l}\text { Lake } \\
\text { (before } \\
20^{\text {th }} \\
\text { century } \\
\text { draining) } \\
\text {; sed. } \\
\text { core and } \\
\text { geophys. } \\
\text { data }\end{array}$ & $\begin{array}{l}\text { Drains into } \\
\text { Searles Lake } \\
\text { via Owens } \\
\text { River during } \\
\text { wet intervals. } \\
\text { Bottom of } \\
\text { oldest sed. } \\
\text { Core is } \sim 800 \\
\text { ka; core is } \\
\text { underlain by } \\
\text { deep basin fill. }\end{array}$ & $\begin{array}{l}\text { Unclear if lake } \\
\text { existed during } \\
\text { KM5c; lake } \\
\text { inferred from } \\
\text { geophys. Data, } \\
\text { extrapolation, } \\
\text { and filling of } \\
\text { Searles Lake }\end{array}$ & $\begin{array}{l}\text { Extrapolatio } \\
\mathrm{n} \text { (Bishop } \\
\text { Tuff to } \\
\text { bottom of } \\
\text { basin fill) }\end{array}$ & $\begin{array}{l}\text { Smith and } \\
\text { Bischoff, } \\
1997\end{array}$ & $\begin{array}{l}\text { Pound et al., } \\
2014\end{array}$ \\
\hline $\begin{array}{l}\text { Coso } \\
\text { Basin }\end{array}$ & $\begin{array}{l}\text { Perennial } \\
\text { lake }\end{array}$ & 2 & 6 & 36.2 & -118 & 143 & 143 & $\begin{array}{l}\text { Dry; } \\
\text { outcrops }\end{array}$ & $\begin{array}{l}\text { Immediately } \\
\text { south of } \\
\text { Owens Lake. } \\
\text { Regional } \\
\text { geophysical } \\
\text { data imply } \\
\text { either 1) Coso } \\
\text { and Owens } \\
\text { were separate } \\
\text { Pliocene lakes, } \\
\text { or 2) Coso } \\
\text { Lake was } \\
\text { ancestral to } \\
\text { Owens Lake. }\end{array}$ & $\begin{array}{l}\text { Evidence of } \\
\text { lacustrine } \\
\text { conditions } \\
\text { continuously } \\
\text { through the } \\
\text { mid-Pliocene. }\end{array}$ & $\begin{array}{l}18 \mathrm{~K}-\mathrm{Ar} \\
\text { ages and } 2 \\
\text { fission track } \\
\text { ages on } \\
\text { volcanics, } \\
\text { NALMA } \\
\text { (Hemphillia } \\
\text { n and } \\
\text { Blancan } \\
\text { fossils) }\end{array}$ & $\begin{array}{l}\text { Bacon et } \\
\text { al., } 1982 . \\
\text { Kamola } \\
\text { and Walker } \\
\text { [1999]'s } \\
\text { age model } \\
\text { places lake } \\
\text { pre-KM5c, } \\
\text { but based } \\
\text { on less } \\
\text { evidence } \\
\text { than Bacon } \\
\text { et al. }\end{array}$ & $\begin{array}{l}\text { Estimated } \\
\text { from areal } \\
\text { extent of } \\
\text { Coso Fm; an } \\
\text { underestimat } \\
\text { e since Coso } \\
\text { Fm. is partly } \\
\text { buried, so } \\
\text { min area is } \\
\text { not } \\
\text { calculated. }\end{array}$ \\
\hline $\begin{array}{l}\text { Amargosa } \\
\text { Marsh }\end{array}$ & $\begin{array}{l}\text { Perennial } \\
\text { lake }\end{array}$ & 2.4 & 3.35 & 36.5 & -116 & 1250 & 625 & $\begin{array}{l}\text { Small } \\
\text { playas; } \\
\text { outcrops, } \\
\text { sed. } \\
\text { cores }\end{array}$ & $\begin{array}{l}\text { Sed. indicates } \\
\text { marshland, } \\
\text { spring-fed } \\
\text { ponds, and } \\
\text { playas, with } \\
\text { gastropods, }\end{array}$ & $\begin{array}{l}\text { No evidence } \\
\text { for dessication } \\
\text { from numerous } \\
\text { sed. cores and } \\
\text { outcrops. }\end{array}$ & $\begin{array}{l}\text { Tephras: K- } \\
\text { Ar date near } \\
\text { top of sed is } \\
2.1+/-0.4 \\
\text { Ma, tephra } \\
\text { near base of }\end{array}$ & $\begin{array}{l}\text { Hoover } \\
\text { 1989, Hay } \\
\text { et al., 1986, } \\
\text { Knott et } \\
\text { al., } 2018\end{array}$ & $\begin{array}{l}\text { Hoover } 1989 \\
\text { Min extent is } \\
1 / 2 \text { max, } \\
\text { from } \\
\text { widespread } \\
\text { evidence for }\end{array}$ \\
\hline
\end{tabular}




\begin{tabular}{|c|c|c|c|c|c|c|c|c|c|c|c|c|c|}
\hline & & & & & & & & & $\begin{array}{l}\text { ostracodes, } \\
\text { and bivalves. }\end{array}$ & & $\begin{array}{l}\text { sed. correl. } \\
\text { to tuff of } \\
\text { Zabriskie } \\
\text { Wash }\end{array}$ & & $\begin{array}{l}\text { wet } \\
\text { conditions } \\
\text { from sed. } \\
\text { cores }\end{array}$ \\
\hline $\begin{array}{l}\text { Copper } \\
\text { Canyon } \\
\text { Fm, Death } \\
\text { Valley }\end{array}$ & $\begin{array}{l}\text { Perennial } \\
\text { lake }\end{array}$ & 3.15 & 4.33 & $\begin{array}{l}36.1 \\
5\end{array}$ & -117 & 1 & 1 & $\begin{array}{l}\text { Dry; } \\
\text { outcrops }\end{array}$ & $\begin{array}{l}\text { Copper } \\
\text { Canyon Fm. is } \\
\text { only accessible } \\
\text { by guided tour, } \\
\text { so is excluded } \\
\text { from most } \\
\text { discussions of } \\
\text { Pliocene lakes } \\
\text { in the region }\end{array}$ & $\begin{array}{l}\text { Evidence of } \\
\text { fresh to saline } \\
\text { spring-fed lake } \\
\text { continuously } \\
\text { through the } \\
\text { mid-Pliocene }\end{array}$ & $\begin{array}{l}\text { Ar-Ar dates } \\
\text { on basalts } \\
\text { bracketing } \\
\text { lake sed. } \\
\text { (4.33 Ma, } \\
3.1 \mathrm{Ma}) \text {, } \\
\text { paleomag. } \\
\text { (Gilbert- } \\
\text { Gauss, } \\
\text { Mammoth } \\
\text { and Cochiti } \\
\text { subchrons) }\end{array}$ & $\begin{array}{l}\text { Nyborg } \\
2011\end{array}$ & $\begin{array}{l}\text { Estimated } \\
\text { from areal } \\
\text { extent of } \\
\text { Copper } \\
\text { Canyon Fm. }\end{array}$ \\
\hline $\begin{array}{l}\text { Searles } \\
\text { Lake }\end{array}$ & $\begin{array}{l}\text { Perennial } \\
\text { lake }\end{array}$ & 2.5 & 3.4 & $\begin{array}{l}35.6 \\
8\end{array}$ & -117 & 800 & 288 & $\begin{array}{l}\text { Playa } \\
\text { and brine } \\
\text { pools; } \\
\text { sed. core }\end{array}$ & $\begin{array}{l}\text { Modern } \\
\text { terminus of } \\
\text { Owens River. } \\
\text { Paleoenvironm } \\
\text { ental } \\
\text { information } \\
\text { from sediment } \\
\text { core KM-3, } \\
\text { first described } \\
\text { by Smith et al., } \\
1983\end{array}$ & $\begin{array}{l}\text { Evidence of } \\
\text { lacustrine } \\
\text { conditions } \\
\text { continuously } \\
\text { through the } \\
\text { mid-Pliocene }\end{array}$ & $\begin{array}{l}\text { Paleomag. } \\
\text { (Mammoth } \\
\text { subchron), } \\
\text { tephra } \\
\text { correl. to } \\
\text { tuffs of } \\
\text { Mesquite } \\
\text { Springs and } \\
\text { Zabriskie } \\
\text { Wash }\end{array}$ & $\begin{array}{l}\text { Smith et } \\
\text { al., 1983; } \\
\text { Knott et } \\
\text { al., } 2018\end{array}$ & $\begin{array}{l}\text { Pound et al., } \\
2014 \text { (their } \\
\text { "China- } \\
\text { Scarles } \\
\text { lake"). Min } \\
\text { from modern } \\
\text { Searles playa } \\
\left(133 \mathrm{~km}^{2}\right)+ \\
\text { adjacent } \\
\text { China basin } \\
\text { playa }(155 \\
\left.\mathrm{km}^{2}\right)\end{array}$ \\
\hline
\end{tabular}


Table S2. Details of PlioMIP2 models used in this analysis.

\begin{tabular}{|c|c|c|c|c|c|c|}
\hline Group & Model & $\begin{array}{l}\text { Atmosphere } \\
\text { Resolution }\end{array}$ & $\begin{array}{l}\text { Ocean } \\
\text { Resolution }\end{array}$ & $\begin{array}{l}\text { South Great } \\
\text { Basin } \Delta T_{s}(C)\end{array}$ & $\begin{array}{l}\text { South } \\
\text { Great Basin } \\
\Delta P\left(\mathrm{~mm} \mathrm{~d}^{-1}\right)\end{array}$ & Reference \\
\hline $\begin{array}{l}\text { University of } \\
\text { Utrecht, the } \\
\text { Netherlands }\end{array}$ & $\begin{array}{l}\text { CESM 1.0.5 (CCSM4) - Utrecht } \\
\text { version }\end{array}$ & $2.5^{\circ} \times 1.9^{\circ}$ & $\sim 1^{\circ}$ & 2.75 & -0.09 & $\begin{array}{l}\text { Baatsen et al., 2021, } \\
\text { in prep. }\end{array}$ \\
\hline $\begin{array}{l}\text { National Center for } \\
\text { Atmospheric } \\
\text { Research, USA }\end{array}$ & CCSM4 & $\sim 1^{\circ}$ & $\sim 1^{\mathrm{o}}$ & 3.05 & -0.17 & Feng et al. 2020 \\
\hline $\begin{array}{l}\text { University of } \\
\text { Toronto, Canada }\end{array}$ & $\begin{array}{l}\text { CESM 1.0.5 (CCSM4) - UoT } \\
\text { version }\end{array}$ & $\sim 1^{\circ}$ & $\sim 1^{\circ}$ & 3.65 & -0.38 & $\begin{array}{l}\text { Chandan and Peltier } \\
2017,2018\end{array}$ \\
\hline $\begin{array}{l}\text { National Center for } \\
\text { Atmospheric } \\
\text { Research, USA }\end{array}$ & CESM1.2 & $\sim 1^{\circ}$ & $\sim 1^{\circ}$ & 4.75 & -0.15 & Feng et al. 2020 \\
\hline $\begin{array}{l}\text { National Center for } \\
\text { Atmospheric } \\
\text { Research, USA }\end{array}$ & CESM2 & $\sim 1^{\circ}$ & $\sim 1^{\circ}$ & 4.69 & 0.22 & Feng et al. 2020 \\
\hline $\begin{array}{l}\text { Alfred Wegener } \\
\text { Institute, Germany }\end{array}$ & COSMOS & $3.75^{\circ} \times 3.75^{\circ}$ & $3.0^{\circ} \times 1.8^{\circ}$ & 2.36 & 0.07 & Stepanek et al., 2020 \\
\hline $\begin{array}{l}\text { Stockholm } \\
\text { University, Sweden }\end{array}$ & EC-Earth3.3 & $\begin{array}{l}1.125^{\circ} \times \\
1.125^{\circ}\end{array}$ & $1.0^{\circ} \times 1.0^{\circ}$ & 6.09 & -0.39 & Zheng et al., 2019 \\
\hline $\begin{array}{l}\text { Goddard Institute } \\
\text { for Space Studies, } \\
\text { USA }\end{array}$ & GISS2.1G & $2.0^{\circ} \times 2.5^{\circ}$ & $1.0^{\circ} \times 1.25^{\circ}$ & 0.74 & -0.20 & Kelley et al., 2020 \\
\hline $\begin{array}{l}\text { Institut Pierre- } \\
\text { Simon Laplace }\end{array}$ & IPSLCM6A & $2.5^{\circ} \times 1.26^{\mathrm{o}}$ & $1.0^{\circ} \times 1.0^{\circ}$ & 3.11 & -0.28 & Lurton et al., 2020 \\
\hline $\begin{array}{l}\text { Japan Agency for } \\
\text { Marine-Earth } \\
\text { Science and } \\
\text { Technology, Japan }\end{array}$ & MIROC4m & $\sim 2.8^{\circ} \times 2.8^{\circ}$ & $0.5^{\mathrm{o}}-1.4^{\mathrm{o}} \times 1.4^{\mathrm{o}}$ & 3.06 & 0.06 & $\begin{array}{l}\text { Chan and Abe- } \\
\text { Ouchi, } 2020\end{array}$ \\
\hline
\end{tabular}




\section{Supplementary references}

Baatsen, M. L. J., von der Heydt, A. S., Oldeman, A. M., Kliphuis, M. A., and Weiffenbach, J. E. Warm mid-Pliocene conditions without high climate sensitivity: the CCSM4-Utrecht (CESM1.0.4) contribution to PlioMIP2, 2021, in prep.

Bacon, C. R., D. M. Giovannetti, W. A. Duffield, G. B. Dalrymple, and R. E. Drake (1982), Age of the Coso Formation, Inyo County, California, Geological Survey Bulletin, 1527.

Bell, C. J., E. L. Lundelius, A. D. Barnosky, R. W. Graham, E. H. Lindsay, D. R. Ruez, H. A. Semken, S. D. Webb, and R. J. Zakrzewski (2004), The Blancan, Irvingtonian, and Rancholabrean Mammal Ages, in Late Cretaceous and Cenozoic Mammals of North America, edited by M. O. Woodburne, pp. 232-314, Columbia University Press, New York.

Brooks, L.E., Masbruch, M.D., Sweetkind, D.S., Buto, S.G., 2014. Steady-state numerical groundwater flow model of the Great Basin carbonate and alluvial aquifer system (USGS Numbered Series No. 2014-5213), Steady-state numerical groundwater flow model of the Great Basin carbonate and alluvial aquifer system, Scientific Investigations Report. U.S. Geological Survey, Reston, VA. https://doi.org/10.3133/sir20145213

Chan, W.-L., Abe-Ouchi, A., 2020. Pliocene Model Intercomparison Project (PlioMIP2) simulations using the Model for Interdisciplinary Research on Climate (MIROC4m). Climate of the Past 16, 1523-1545. https://doi.org/10.5194/cp-16-1523-2020

Chandan, D., Peltier, W.R., 2017. Regional and global climate for the mid-Pliocene using the University of Toronto version of CCSM4 and PlioMIP2 boundary conditions. Climate of the Past 13, 919-942. https://doi.org/10.5194/cp-13-919-2017

Chandan, D., Peltier, W.R., 2018. On the mechanisms of warming the mid-Pliocene and the inference of a hierarchy of climate sensitivities with relevance to the understanding of climate futures. Climate of the Past 14, 825-856. https://doi.org/10.5194/cp-14-825-2018

Coffey, D. M., L. A. Munk, D. E. Ibarra, K. L. Butler, and J. Jenckes (in review), Lithium storage and release from lacustrine clays: implications for lithium enrichment and sustainability in continental brines, Geochemistry, Geophysics, Geosystems.

Dowsett, H., Dolan, A., Rowley, D., Moucha, R., Forte, A.M., Mitrovica, J.X., Pound, M., Salzmann, U., Robinson, M., Chandler, M., Foley, K., Haywood, A., 2016. The PRISM4 (mid-Piacenzian) paleoenvironmental reconstruction. Climate of the Past 12, 1519-1538. https://doi.org/10.5194/cp-12-1519-2016

Draper, C.S., Reichle, R.H., Koster, R.D., 2018. Assessment of MERRA-2 Land Surface Energy Flux Estimates. Journal of Climate 31, 671-691. https://doi.org/10.1175/JCLI-D-17$\underline{0121.1}$

Feng, R., Otto-Bliesner, B.L., Brady, E.C., Rosenbloom, N., 2020. Increased Climate Response and Earth System Sensitivity From CCSM4 to CESM2 in Mid-Pliocene Simulations. Journal of Advances in Modeling Earth Systems 12, e2019MS002033. https://doi.org/10.1029/2019MS002033

Gelaro, R., McCarty, W., Suárez, M.J., Todling, R., Molod, A., Takacs, L., Randles, C.A., Darmenov, A., Bosilovich, M.G., Reichle, R., Wargan, K., Coy, L., Cullather, R., Draper, C., Akella, S., Buchard, V., Conaty, A., Silva, A.M. da, Gu, W., Kim, G.-K., Koster, R., Lucchesi, R., Merkova, D., Nielsen, J.E., Partyka, G., Pawson, S., Putman, W., Rienecker, M., Schubert, S.D., Sienkiewicz, M., Zhao, B., 2017. The Modern-Era 
Retrospective Analysis for Research and Applications, Version 2 (MERRA-2). Journal of Climate 30, 5419-5454. https://doi.org/10.1175/JCLI-D-16-0758.1

Gilbert, C. M., M. N. Christensen, Y. Al-Rawi, and K. R. Lajoie (1968), Structural and volcanic history of Mono Basin, California-Nevada, GSA Memoir, 116, 275-329.

Global Modeling and Assimilation Office (GMAO) (2015), MERRA-2 inst3_3d_asm_Np: 3d,3Hourly,Instantaneous,Pressure-Level,Assimilation,Assimilated Meteorological Fields V5.12.4, Greenbelt, MD, USA, Goddard Earth Sciences Data and Information Services Center (GES DISC), Accessed: 2 June 2021, 10.5067/QBZ6MG944HW0

Global Modeling and Assimilation Office (GMAO) (2015), MERRA-2 tavg1_2d_flx_Nx: 2d,1Hourly,Time-Averaged,Single-Level,Assimilation,Surface Flux Diagnostics V5.12.4, Greenbelt, MD, USA, Goddard Earth Sciences Data and Information Services Center (GES DISC), Accessed: 7 May 2021, 10.5067/7MCPBJ41Y0K6

Global Modeling and Assimilation Office (GMAO) (2015), MERRA-2 tavg1_2d_rad_Nx: 2d,1Hourly,Time-Averaged,Single-Level,Assimilation, Radiation Diagnostics V5. $\overline{12.4}$, Greenbelt, MD, USA, Goddard Earth Sciences Data and Information Services Center (GES DISC), Accessed: 7 May 2021, 10.5067/Q9QMY5PBNV1T

Google Earth 2021. 2-D map of South Great Basin region. Accessed May 2021.

Hay, R. L., R. E. Pexton, T. T. Teague, and T. K. Kyser (1986), Spring-related carbonate rocks, $\mathrm{Mg}$ clays, and associated minerals in Pliocene deposits of the Amargosa Desert, Nevada and California, GSA Bulletin, 97, 1488-1503.

Haywood, A.M., Dowsett, H.J., Dolan, A.M., Rowley, D., Abe-Ouchi, A., Otto-Bliesner, B., Chandler, M.A., Hunter, S.J., Lunt, D.J., Pound, M., Salzmann, U., 2016. The Pliocene Model Intercomparison Project (PlioMIP) Phase 2: scientific objectives and experimental design. Climate of the Past 12, 663-675. https://doi.org/10.5194/cp-12-663-2016

Haywood, A.M., Tindall, J.C., Dowsett, H.J., Dolan, A.M., Foley, K.M., Hunter, S.J., Hill, D.J., Chan, W.-L., Abe-Ouchi, A., Stepanek, C., Lohmann, G., Chandan, D., Peltier, W.R., Tan, N., Contoux, C., Ramstein, G., Li, X., Zhang, Z., Guo, C., Nisancioglu, K.H., Zhang, Q., Li, Q., Kamae, Y., Chandler, M.A., Sohl, L.E., Otto-Bliesner, B.L., Feng, R., Brady, E.C., von der Heydt, A.S., Baatsen, M.L.J., Lunt, D.J., 2020. The Pliocene Model Intercomparison Project Phase 2: large-scale climate features and climate sensitivity. Climate of the Past 16, 2095-2123. https://doi.org/10.5194/cp-16-2095-2020

Hoover, D. L. (1989), Preliminary description of Quaternary and lake Pliocene surficial deposits at Yucca Mountain and vicinity, Nye County NevadaRep., Nevada Operations Office, U.S. Dept. of Energy.

Kamola, D. L., and J. D. Walker (1999), Geologic study of the Coso Formation, edited, U.S. Dept. of Energy, University of Kansas, Lawrence, KS.

Kelley, M., Schmidt, G.A., Nazarenko, L.S., Bauer, S.E., Ruedy, R., Russell, G.L., Ackerman, A.S., Aleinov, I., Bauer, M., Bleck, R., Canuto, V., Cesana, G., Cheng, Y., Clune, T.L., Cook, B.I., Cruz, C.A., Del Genio, A.D., Elsaesser, G.S., Faluvegi, G., Kiang, N.Y., Kim, D., Lacis, A.A., Leboissetier, A., LeGrande, A.N., Lo, K.K., Marshall, J., Matthews, E.E., McDermid, S., Mezuman, K., Miller, R.L., Murray, L.T., Oinas, V., Orbe, C., García-Pando, C.P., Perlwitz, J.P., Puma, M.J., Rind, D., Romanou, A., Shindell, D.T., Sun, S., Tausnev, N., Tsigaridis, K., Tselioudis, G., Weng, E., Wu, J., Yao, M.-S., 2020. GISS-E2.1: Configurations and Climatology. Journal of Advances in Modeling Earth Systems 12, e2019MS002025. https://doi.org/10.1029/2019MS002025 
Knott, J. R., E. Wan, A. L. Deino, M. Casteel, M. C. Reheis, F. M. Phillips, L. Walkup, K. McCarty, D. N. Manoukian, and E. Nunez (2019), Lake Andrei: A Pliocene pluvial lake in Eureka Valley, eastern California, in From Saline to Freshwater: The Diversity of Western Lakes in Space and Time, edited.

Knott, J. R., et al. (2018), Late Neogene-Quaternary tephrochronology, stratigraphy, and paleoclimate of Death Valley, California, USA, GSA Bulletin, 130(7-8), 1231-1255, doi: 10.1130/b31690.1.

Lehner, B., Grill, G., 2013. Global river hydrography and network routing: baseline data and new approaches to study the world's large river systems. Hydrological Processes 27, $2171-$ 2186. https://doi.org/10.1002/hyp.9740

Lindsay, E., Y. Mou, W. Downs, J. Pederson, T. S. Kelly, C. Henry, and J. Trexler (2002), Recognition of the Hemphillian/Blancan boundary in Nevada, Journal of Vertebrate Paleontology, 22(2), 429-442, doi: 10.1671/0272-4634(2002)022[0429:Rothbb]2.0.Co;2.

Lurton, T., Balkanski, Y., Bastrikov, V., Bekki, S., Bopp, L., Braconnot, P., Brockmann, P., Cadule, P., Contoux, C., Cozic, A., Cugnet, D., Dufresne, J.-L., Éthé, C., Foujols, M.-A., Ghattas, J., Hauglustaine, D., Hu, R.-M., Kageyama, M., Khodri, M., Lebas, N., Levavasseur, G., Marchand, M., Ottlé, C., Peylin, P., Sima, A., Szopa, S., Thiéblemont, R., Vuichard, N., Boucher, O., 2020. Implementation of the CMIP6 Forcing Data in the IPSL-CM6A-LR Model. Journal of Advances in Modeling Earth Systems 12, e2019MS001940. https://doi.org/10.1029/2019MS001940

Miller, R. R., and G. R. Smith (1981), Distribution and evolution of Chasmistes (Pisces: Catostomidae) in western North America, Occasional Papers of the Museum of Zoology, University of Michigan, 696.

Nyborg, T. (2011), Age, stratigraphy, and depositional environment of the Pliocene Copper Canyon Formation, Death Valley, California, PhD thesis, Loma Linda University.

Ogg, J. G. (2012), Geomagnetic Polarity Time Scale, in The Geologic Time Scale, edited, pp. 85-113.

Open Street Map Contributors, 2021. Map of South Great Basin region. www.openstreetmap.org. Accessed May 2021

Pound, M. J., J. Tindall, S. J. Pickering, A. M. Haywood, H. J. Dowsett, and U. Salzmann (2014), Late Pliocene lakes and soils: a global data set for the analysis of climate feedbacks in a warmer world, Climate of the Past, 10(1), 167-180, doi: 10.5194/cp-10167-2014.

Reichle, R.H., Liu, Q., Koster, R.D., Draper, C.S., Mahanama, S.P.P., Partyka, G.S., 2017. Land Surface Precipitation in MERRA-2. Journal of Climate 30, 1643-1664. https://doi.org/10.1175/JCLI-D-16-0570.1

Reheis, M. C., A. M. Sarna-Wojcicki, D. M. Burbank, and C. E. Meyer (1991), The late Cenozoic section at Willow Wash, west-central California: a tephrachronologic Rosetta Stone, in Late Cenozoic Stratigraphy and Tectonics of Fish Lake Valley, Nevada and California: Road Log and Contributions to the Field Trip Guidebook, 1991 Pacific Cell, Friends of the Pleistocene, edited, U.S. Geological Survey, Open-File Report 91-290.

Reheis, M. C., A. M. Sarna-Wojcicki, R. L. Reynolds, C. A. Repenning, and M. D. Mifflin (2002), Pliocene to Middle Pleistocene Lakes in the western Great Basin: ages and connections, in Great Basin Aquatic Systems History, edited by R. Hershler, D. B. Madsen and D. R. Currey, Smithsonian Contributions to the Earth Sciences, Washington, D.C. 
Rush, F. E. (1968), Water-resources appraisal of Clayton Valley-Stonewall Flat area, Nevada and California, in Water Resources - Reconnaissance Series Report 45, edited, State of Nevada Dept. of Conservation and Natural Resources, U.S. Geological Survey.

Smith, G.I., Street-Perrott, F.A., 1983. Pluvial Lakes of the Western United States, in: The Late Pleistocene. University Minn Press, Minneapolis, pp. 190-211.

Smith, G.I., 1984. Paleohydrologic regimes in the southwestern Great Basin, 0-3.2 my ago, compared with other long records of "gobal" climate. Quaternary Research 22, 1-17. https://doi.org/10.1016/0033-5894(84)90002-4

Smith, G. I., and J. L. Bischoff (1997), Core OL-92 from Owens Lake: Project rationale, geologic setting, drilling procedures, and summary, in An 800,000-Year Paleoclimatic Record from Core OL-92, Owens Lake, Southeast California, edited by G. I. Smith and J. L. Bischoff, GSA Special Paper, Boulder, Colorado.

Smith, G. I., V. J. Barczak, G. F. Moulton, and J. C. Liddicoat (1983), Core KM-3, a surface-tobedrock record of late Cenozoic sedimentation in Searles Valley, California, Geological Survey Professional Paper, 1256.

Stepanek, C., Samakinwa, E., Knorr, G., Lohmann, G., 2020. Contribution of the coupled atmosphere-ocean-sea ice-vegetation model COSMOS to the PlioMIP2. Climate of the Past 16, 2275-2323. https://doi.org/10.5194/cp-16-2275-2020

Reheis, M.C., 1997. Dust deposition downwind of Owens (dry) Lake, 1991-1994: Preliminary findings. Journal of Geophysical Research: Atmospheres 102, 25999-26008. https://doi.org/10.1029/97JD01967

Uranium Resources, I. (2017), Uranium Resources announces positive geophysical results at its Columbus Basin lithium project, edited by U. S. S. a. E. Commission, SEC filing.

Zheng, J., Zhang, Qiong, Li, Q., Zhang, Qiang, Cai, M., 2019. Contribution of sea ice albedo and insulation effects to Arctic amplification in the EC-Earth Pliocene simulation. Climate of the Past 15, 291-305. https://doi.org/10.5194/cp-15-291-2019 